\title{
Enriched Expression of GluD1 in Higher Brain Regions and Its Involvement in Parallel Fiber-Interneuron Synapse Formation in the Cerebellum
}

\author{
Kohtarou Konno, ${ }^{1}$ Keiko Matsuda, ${ }^{2}$ Chihiro Nakamoto, ${ }^{3}$ Motokazu Uchigashima, ${ }^{1}$ Taisuke Miyazaki, ${ }^{1}$ \\ Miwako Yamasaki, ${ }^{1}$ Kenji Sakimura, ${ }^{3,4}$ Michisuke Yuzaki, ${ }^{2,4}$ and Masahiko Watanabe ${ }^{1,4}$ \\ ${ }^{1}$ Department of Anatomy, Hokkaido University Graduate School of Medicine, Sapporo 060-8638, Japan; 2Department of Physiology, School of Medicine, \\ Keio University, Tokyo 160-8582, Japan; ${ }^{3}$ Department of Cellular Neurobiology, Brain Research Institute, Niigata University, Niigata 951-8585, Japan, and \\ ${ }^{4}$ Core Research for Evolutional Science and Technology, Japan Science and Technology Agency, Sanbancho, Chiyoda-ku, Tokyo 102-0075, Japan
}

Of the two members of the $\delta$ subfamily of ionotropic glutamate receptors, GluD2 is exclusively expressed at parallel fiber-Purkinje cell (PF-PC) synapses in the cerebellum and regulates their structural and functional connectivity. However, little is known to date regarding cellular and synaptic expression of GluD1 and its role in synaptic circuit formation. In the present study, we investigated this issue by producing specific and sensitive histochemical probes for GluD1 and analyzing cerebellar synaptic circuits in GluD1-knock-out mice. GluD1 was widely expressed in the adult mouse brain, with high levels in higher brain regions, including the cerebral cortex, striatum, limbic regions (hippocampus, nucleus accumbens, lateral septum, bed nucleus stria terminalis, lateral habenula, and central nucleus of the amygdala), and cerebellar cortex. In the cerebellar cortex, GluD1 mRNA was expressed at the highest level in molecular layer interneurons and its immunoreactivity was concentrated at PF synapses on interneuron somata. In GluD1-knock-out mice, the density of PF synapses on interneuron somata was significantly reduced and the size and number of interneurons were significantly diminished. Therefore, GluD1 is common to GluD2 in expression at PF synapses, but distinct from GluD2 in neuronal expression in the cerebellar cortex; that is, GluD1 in interneurons and GluD2 in PCs. Furthermore, GluD1 regulates the connectivity of PF-interneuron synapses and promotes the differentiation and/or survival of molecular layer interneurons. These results suggest that GluD1 works in concert with GluD2 for the construction of cerebellar synaptic wiring through distinct neuronal and synaptic expressions and also their shared synapse-connecting function.

Key words: Cerebellum; GluD1; GluR $\delta 1$; glutamate receptor; mouse; synapse

\section{Introduction}

The $\delta$ subfamily of ionotropic glutamate receptors shares $17-$ $28 \%$ amino acid identity with other subfamilies and consists of

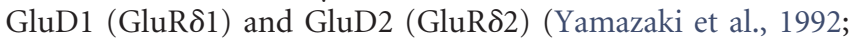
Lomeli et al., 1993). Despite well conserved membrane topology and amino acid residues critical to ligand binding and $\mathrm{Ca}^{2+}$ permeability, the $\delta$ subfamily do not function as conventional glutamate-gated ion channels (Hirai et al., 2005; Kakegawa et al., 2007a, 2007b; Ady et al., 2014). Essential roles of GluD2 in syn-

\footnotetext{
Received Feb. 13, 2014; revised April 15, 2014; accepted April 16, 2014.

Author contributions: M. Yuzaki and M.W. designed research; K.K., K.M., and C.N. performed research;M.U., T.M., M. Yamasaki, K.S., and M.W. contributed unpublished reagents/analytic tools; K.K. analyzed data; M.W. wrote the paper.

This work was supported by the Core Research for Evolutional Science and Technology from the JST Agency and by the Ministry of Education, Culture, Sports, Science and Technology of Japan (Grants-in-Aid for Scientific Research 24220007 to M.W. and 25860982 to K.K and a grant for "Integrated Research on Neuropsychiatric Disorders" carried out under the Strategic Research Program for Brain Sciences to M.M. and M.W.). We thank Dr. J. Zuo (St. Jude Children's Research Hospital) for GluD1-K0 mice.

The authors declare no competing financial interests.

Correspondence should be addressed to Masahiko Watanabe, Department of Anatomy, Hokkaido University Graduate School of Medicine, Sapporo 060-8638, Japan. E-mail: watamasa@med.hokudai.ac.jp.

DOI:10.1523/JNEUROSCI.0628-14.2014

Copyright $\odot 2014$ the authors $\quad 0270-6474 / 14 / 347412-13 \$ 15.00 / 0$
}

aptic development and plasticity have been established through intensive analyses on GluD2-defective mice (Yuzaki, 2009; Watanabe and Kano, 2011).

GluD2 is expressed exclusively at parallel fiber (PF) synapses on cerebellar Purkinje cells (PCs) (Takayama et al., 1996; Landsend et al., 1997) and weakly in PF synapses on interneuron dendrites (Yamasaki et al., 2011). GluD2 plays a key role in the formation and maintenance of PF-PC synapses (Guastavino et al., 1990; Kashiwabuchi et al., 1995; Kurihara et al., 1997; Lalouette et al., 2001; Takeuchi et al., 2005); this is mediated through selective binding of the N-terminal domain of GluD2 with presynaptic neurexins via granule cell-derived Cbln1 (Matsuda et al., 2010; Uemura et al., 2010). GluD2 is also essential for induction of cerebellar long-term depression at PF-PC synapses (Kashiwabuchi et al., 1995), through interaction of the C-terminus with megakaryocyte protein tyrosine phosphatase (Kohda et al., 2013), and through binding of D-serine to the ligand-binding site (Hirai et al., 2003; Kakegawa et al., 2011; Kohda et al., 2013). Mutation of the GluD2 gene in mice and humans (Grid2 and GRID2, respectively) causes cerebellar ataxia (Kashiwabuchi et al., 1995; Hills et al., 2013; Utine et al., 2013). 
Table 1. Primary antibodies used in the present study

\begin{tabular}{lllll}
\hline Molecule & Sequence (NCBI \#) & Host & Specificity & Reference/source \\
\hline Bassoon & Rat bassoon & Ms & & Enzo Life Sciences (SAP7F407) \\
GluD1 & 895-932aa (NM_008166) & Rb,GP & K0 & Present study \\
GluD2 & 897-934aa (NM_008167) & GP & K0 & Present study \\
MAP2 & 927-1104 (NM008632) & Go & $*$ & $\begin{array}{l}\text { Miura et al. (2006) } \\
\text { Covance Research Products }\end{array}$ \\
HA & HA.11 epitope & Ms & & (clone 16B2) \\
Parvalbumin & 1-110aa (NM_013645) & GP & IB & Nakamura et al., 2004 \\
VGluT1 & 531-560aa (BC054462) & Rb,GP & IB & Miyazaki et al., 2003 \\
VGluT2 & 559-582aa (BC038375) & GP & IB & Miyazaki et al., 2003
\end{tabular}

Go, Goat polyclonal antibody; GP, guinea pig polyclonal antibody; IB, immunoblot with brain homogenates; KO, lack of immunohistochemical or immunoblot labeling in knockout mice; Ms, mouse monoclonal antibody; Rb, rabbit polyclonal antibody.

*The specificity of the MAP2 antibody is supported by selective labeling of somatodendritic neuronal elements (see the reference).

In comparison, GluD1 is transcribed weakly in various brain regions (Lomeli et al., 1993). The functional significance of GluD1 is inferred from human genetic studies reporting that the GRID1 is a strong candidate gene for schizophrenia, bipolar disorder, major depressive disorder, and autism spectrum disorder (Fallin et al., 2005; Guo et al., 2007; Glessner et al., 2009; Smith et al., 2009; Treutlein et al., 2009; Cooper et al., 2011; Greenwood et al., 2011; Edwards et al., 2012 Griswold et al., 2012). GluD1knock-out $(\mathrm{KO})$ mice also exhibit deficits in emotional and social behaviors and in learning and memory (Yadav et al., 2012, 2013). Like GluD2, GluD1 binds to neurexins via the Cbln family and their interaction induces synaptogenesis in vitro (Matsuda et al., 2010, Yasumura et al., 2012; Ryu et al., 2012). These findings suggest that GluD1 is involved in higher brain functions through controlling synaptic connectivity and plasticity. However, fundamental information on cellular and synaptic expression of GluD1 and its functional role, which is essential to link the genetic level to the behavioral and disorder level, is missing to date.

In the present study, we report that GluD1 is widespread in adult mouse brains, with abundant expression in the cerebral cortex, striatum, limbic regions, and cerebellar cortex. In the cerebellar cortex, GluD1 is enriched at PF synapses on molecular layer interneurons and GluD1-KO mice manifested significant losses of interneurons and PF-interneuron synapses.

\section{Materials and Methods}

Animals. In the present study, we used adult C57BL/6 mice, GluD1-KO mice (Gao et al., 2007), and GluD2-KO mice (Yamasaki et al., 2011) at 2-3 months of age. In each experiment, we used three male mice for qualitative and quantitative analyses. All experiments were performed according to the guidelines laid down by the animal welfare committees of Hokkaido University, Keio University, and Niigata University.

Antibodies. Primary antibodies raised against the following molecules were used: microtubule-associated protein 2 (MAP2), vesicular glutamate transporter (VGluT) 1, VGluT2, parvalbumin, and bassoon. In the present study, we produced GluD1 and GluD2 antibodies. For expression of glutathione S-transferase fusion proteins, we subcloned cDNA fragments encoding the corresponding C-terminal regions of mouse GluD1 (895-932 aa residues) and GluD2 (897-934 aa residues) into the BamHI/EcoRI site of pGEX4T-2 plasmid (GE Healthcare). Immunization and affinity purification were performed as described previously (Watanabe et al., 1998). Information on the antigen, host species, source, reference, and specificity is summarized in Table 1 .

Immunoblot. To confirm the specificity of GluD1 and GluD2 antibodies, human embryonic kidney 293 (HEK293) cells (CRL-1573; American Type Culture Collection) were transfected with $10 \mu \mathrm{g}$ of pCAGGS vector (provided by Dr. J. Miyazaki, Tohoku University, Sendai, Japan) carrying human influenza hemagglutinin (HA)-tagged GluD1 or GluD2 cDNA using the calcium phosphate method. HA cDNA was added immediately downstream of the signal sequence of GluD1 or GluD2. HEK293 cells $36-48 \mathrm{~h}$ after transfection or mouse brain regions were solubilized in TNE buffer ( 50 mм NaF, 1\% NP-40, 20 mм EDTA, $1 \mu \mathrm{m}$ pepstatin A, 2 $\mu \mathrm{g} / \mathrm{ml}$ leupeptin, $10 \mu \mathrm{g} / \mathrm{ml}$ aprotinin, and $50 \mathrm{~mm}$ Tris- $\mathrm{HCl}, \mathrm{pH} 8.0$ ) with $0.1 \%$ SDS. The soluble fractions were analyzed by immunoblotting with $1 \mu \mathrm{g} / \mathrm{ml}$ of GluD1 and GluD2 antibodies or with HA antibody (mouse, 1:1000; Covance Research Products).

The cerebellum, hippocampus, and cerebral cortex were excised and homogenized in homogenate buffer $(0.32 \mathrm{~m}$ sucrose, $5 \mathrm{~mm}$ EDTA, $5 \mathrm{~mm}$ HEPES- $\mathrm{NaOH}, \mathrm{pH}$ 7.4, complete protease inhibitor mixture tablet; Roche) and centrifuged at $1000 \times g$ for $10 \mathrm{~min}$ to obtain the $\mathrm{S} 1$ (homogenate) fraction. Synaptosome and postsynaptic density (PSD) fractions were prepared according to the method used by Carlin et al. (1980). Protein samples of each fraction were subjected to SDS-PAGE for immunoblotting as described previously (Abe et al., 2004). Signal intensities of immunoreacted bands were determined using an Ez-Capture MG (ATTO) and their statistical differences were evaluated using a Student's unpaired $t$ test with Welch's correction.

Immunocytochemistry. In immunocytochemical experiments, transfected HEK293 cells were fixed with $4 \%$ paraformaldehyde for $10 \mathrm{~min}$ at room temperature and incubated with a blocking solution ( $2 \%$ goat serum, $2 \%$ BSA, and $0.4 \%$ Triton X-100 in PBS) for $1 \mathrm{~h}$. Cells were then incubated with mouse HA antibody (1:1000) and with GluD1 or GluD2 antibody $(1 \mu \mathrm{g} / \mathrm{ml})$ for $1 \mathrm{~h}$. To visualize the bound primary antibody, the cells were incubated with Alexa Fluor 546- or Alexa Fluor 488conjugated secondary antibodies (1:2000) to mouse, guinea pig, or rabbit IgG (Invitrogen).

Fixation and sections. Under deep pentobarbital anesthesia $(100 \mathrm{mg} / \mathrm{kg}$ body weight, i.p.), mice were fixed by transcardial perfusion with $4 \%$ paraformaldehyde (PFA) in $0.1 \mathrm{M}$ phosphate buffer (PB; pH 7.2) for immunofluorescence (except for GluD1) and chromogenic in situ hybridization; $2 \% \mathrm{PFA} / 2 \%$ glutaraldehyde in $0.1 \mathrm{~m}$ sodium cacodylate buffer, $\mathrm{pH}$ 7.2, for conventional electron microscopy; and 1\% PFA/0.1\% glutaraldehyde in $0.1 \mathrm{M}$ PB for postembedding immunogold electron microscopy.

For immunofluorescence, except for GluD1 and GluD2, 50- $\mu$ m-thick sections were prepared on a microslicer (VT1000S; Leica Microsystems) and subjected to free-floating incubation. Perfused brains for chromogenic in situ hybridization were further postfixed for $3 \mathrm{~d}$ at room temperature, according to the method of Hioki et al. (2010), and cryoprotected with $30 \%$ sucrose in $0.1 \mathrm{M} \mathrm{PB} ; 30 \mu \mathrm{m}$ cryosections were then prepared on a cryostat (CM1900; Leica Microsystems). For fluorescence in situ hybridization (FISH) and immunofluorescence for GluD1, brains were freshly obtained under deep pentobarbital anesthesia and immediately frozen in powdered dry ice for preparation of fresh frozen sections $(20 \mu \mathrm{m})$. Before incubation for FISH and immunohistochemistry, fresh frozen sections were air-dried and fixed by dipping in 4\% PFA in $0.1 \mathrm{M} \mathrm{PB}$ for $15 \mathrm{~min}$. For GluD2 immunofluorescence, paraffin sections ( $4 \mu \mathrm{m}$; SM1000R; Leica Microsystems) mounted on silane-coated glass slides were subjected, before immunohistochemical reaction, to pepsin pretreatment for antigen exposure, as descrebed previously (Watanabe et al., 1998).

For conventional electron microscopy, the straight portion of lobule $4 / 5$ was excised, postfixed with $1 \%$ osmium tetroxide for $15 \mathrm{~min}$, stained in block with $2 \%$ uranyl acetate for $30 \mathrm{~min}$, dehydrated, and embedded in Epon812. For postembedding immunogold electron microscopy, microslicer sections $(400 \mu \mathrm{m})$ were cryoprotected with $30 \%$ glycerol in $\mathrm{PB}$ and frozen rapidly with liquid propane in the EM CPC unit (Leica Microsystems). Frozen sections were immersed in $0.5 \%$ uranyl acetate in methanol at $-90^{\circ} \mathrm{C}$ in the AFS freeze-substitution unit (Leica Microsystems), infiltrated at $-45^{\circ} \mathrm{C}$ with Lowicryl $\mathrm{HM}-20$ resin (Chemische Werke Lowi), and polymerized with ultraviolet light. Ultrathin sections were made using an Ultracut ultramicrotome (Leica Microsystems).

In situ hybridization. Mouse cDNA fragments of GluD1 (nucleotides 63-3092 bp; GenBank accession number, NM_008166), VGluT1 (3011680, BC054462), and $67 \mathrm{kDa}$ glutamic acid decarboxylase (GAD67; 1035-2015; NM_008077) were subcloned into the pBluescript II plasmid vector. Digoxigenin (DIG)- or fluorescein-labeled cRNA probes were 
transcribed in vitro for chromogenic and FISH (Yamasaki et al., 2010). Fragmentation of riboprobes by alkaline digestion was omitted to increase the sensitivity and specificity. For immunohistochemical detection of DIG and fluorescein, sections were blocked with DIG blocking solution [TNT buffer containing 1\% blocking reagent (Roche Diagnostics) and 4\% normal sheep serum] for $30 \mathrm{~min}$ and $0.5 \%$ TSA blocking reagent (PerkinElmer) in TNT buffer for $30 \mathrm{~min}$. Sections were then incubated with either alkaline-phosphatase-conjugated sheep anti-DIG (1:500, $1.5 \mathrm{~h}$; Roche Diagnostics) for chromogenic detection or peroxidaseconjugated anti-DIG (1:1000, $1 \mathrm{~h}$; Roche Diagnostics) or anti-fluorescein antibody (1: 1500, $1 \mathrm{~h}$; Invitrogen) for fluorogenic detection. After two washes in TNT buffer for 15 min each, chromogenic detection was performed using nitro-blue tetrazolium and 5-bromo-4-chloro- 3 '-indolyphosphate (1:50; Roche Diagnostics) in detection buffer $(0.1 \mathrm{M}$ Tris- $\mathrm{HCl}, \mathrm{pH} 9.5,0.1 \mathrm{M} \mathrm{NaCl}$, and $50 \mathrm{~mm}$ $\mathrm{MgCl}_{2}$ ) for $12 \mathrm{~h}$. For double FISH, the first detection was performed with peroxidaseconjugated anti-fluorescein antibody, followed by incubation with the FITC-TSA Plus amplification kit (PerkinElmer). After inactivation of residual peroxidase activity by dipping sections in $1 \% \mathrm{H}_{2} \mathrm{O}_{2}$ for $30 \mathrm{~min}$, the second detection was performed by incubating sections in DIG-labeled cRNA probe, followed by peroxidase-conjugated anti-DIG antibody and the Cy3-TSA plus amplification kit (PerkinElmer). Sections were counterstained with TOTO-3 (1:50 in PBS, 20 min; Invitrogen). Images of chromogenic in situ hybridization were taken with a light microscope (BZ-9000; Keyence) and PlanApo $(4 \times / 0.20$ and $10 \times /$ 0.45 ) objective lenses (Nikon), and images of FISH were captured using confocal laserscanning microscope as described in the section called Immunofluorescence.

Expression levels of GluD1 mRNA were semiquantitatively evaluated from FISH images taken using the gain level settings. The separate color components were converted to grayscale and the gray level (arbitrary units) and area were measured using MetaMorph software (Molecular Devices) from individual somata of GAD67 mRNA-positive neurons or from regions containing multiple GAD67 mRNA-negative/TOTO-3-labeled neurons (i.e., pyramidal cells in the hippocampus and granule cells in the cerebellum). In the latter, the gray level of a given region was divided by the number of TOTO-3-labeled neurons to calculate the mean relative intensity in each neuron type.

Immunofluorescence. All immunohistochemical incubations were performed at room temperature. Sections were incubated with $10 \%$ normal donkey serum for $20 \mathrm{~min}$, a mixture of primary antibodies overnight (1:1000 dilution for bassoon and $1 \mu \mathrm{g} / \mathrm{ml}$ for others), and a mixture of Alexa Fluor 488-, Cy3-, or Alexa Fluor 647-labeled species-specific secondary antibodies for $2 \mathrm{~h}$ at a dilution of 1:200 (Invitrogen; Jackson ImmunoResearch). Im-
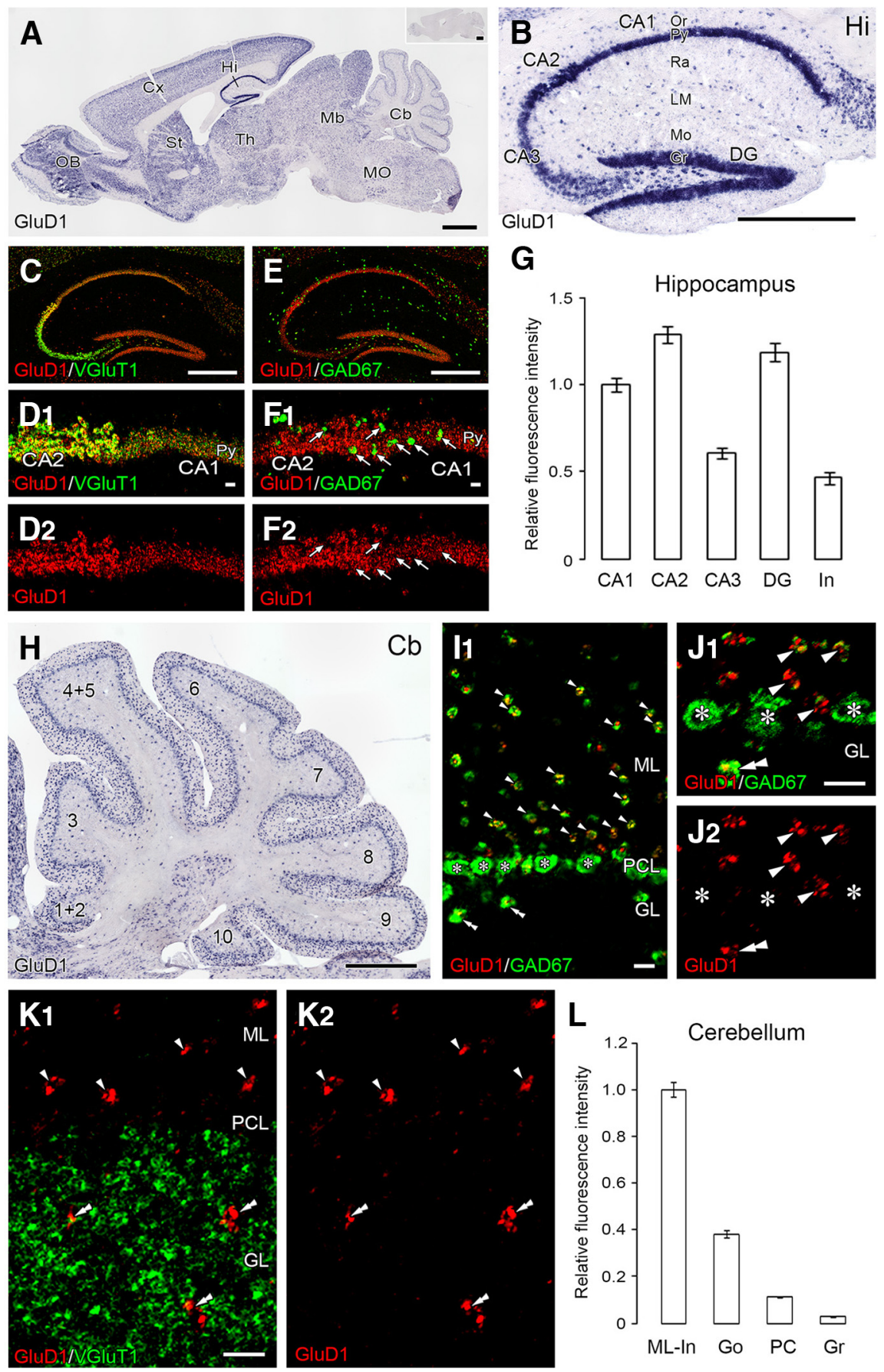

Figure 1. In situ hybridization for GluD1 mRNA in the adult mouse brain. $A, B, H$, Chromogenic in situ hybridization for GluD1 in the whole brain $(\boldsymbol{A})$, hippocampus $(\boldsymbol{B})$, and cerebellum $(\boldsymbol{H})$. Hybridization with a sense probe yielded no significant signal $(\boldsymbol{A}$, inset). $\boldsymbol{C}, \boldsymbol{D}, \boldsymbol{K}$, Fluorescent in situ hybridization for GluD1 (red) and VGluT1 (green) mRNAs in the hippocampus (C, D) and cerebellar cortex $(\boldsymbol{K})$. Arrowheads and double arrowheads in $\boldsymbol{K}$ indicate molecular layer interneurons or Golgi cells, respectively. $\boldsymbol{E}, \boldsymbol{F}, \boldsymbol{I}, \boldsymbol{J}$, FISH for GluD1 (red) and GAD67 (green) mRNAs in the hippocampus $(\boldsymbol{E}, \boldsymbol{F})$ and cerebellar cortex $(\boldsymbol{I}, \boldsymbol{J})$. Arrows in $\boldsymbol{F}$ indicate interneurons that express GAD67 mRNA. Arrowheads and double arrowheads in $I$ and $J$ indicate molecular layer interneurons or Golgi cells, respectively. Asterisks indicate PC somata. $\mathbf{G}, \boldsymbol{L}$, Histograms showing the mean relative fluorescence intensity of GluD1 mRNA in hippocampal $(\boldsymbol{G})$ and cerebellar $(\boldsymbol{L})$ neurons. The intensity in each neuron type was normalized to the intensity in CA1 pyramidal cells in the hippocampus ( $n=133$ for CA1 pyramidal cells, $n=43$ for CA2 pyramidal cells, $n=48$ for CA3 pyramidal cells; $n=65$ for dentate gyrus granule cells, and $n=53$ for hippocampal interneurons) and to the intensity in molecular layer interneurons in the cerebellum ( $n=53$ for molecular layer interneurons, $n=49$ for Golgi cells, $n=57$ for PCs, and $n=243$ for granule cells). CA1-3, CA1-3 regions of the Ammon's horn; Cb, cerebellum; $\mathrm{Cx}$, cortex; DG, dentate gyrus; GL, granular layer; Go, Golgi cell; Gr, granule cell or granule cell layer; $\mathrm{Hi}$, hippocampus; LM, stratum lacunosum-moleculare; Mb, midbrain; ML, molecular layer; M0, medulla oblongata; $\mathrm{Mo}$, molecular layer; $\mathrm{OB}$, olfactory bulb; $0 \mathrm{r}$, stratum oriens; $\mathrm{PCL}$, Purkinje cell layer; Py, pyramidal cell layer; Ra, stratum radiatum; St, striatum; Th, thalamus. Scale bars: $\boldsymbol{A}, 1 \mathrm{~mm} ; \boldsymbol{B}, \boldsymbol{C}, \boldsymbol{E}, \boldsymbol{H}, 500 \mu \mathrm{m} ; \boldsymbol{D}, \boldsymbol{F}, \boldsymbol{I}, \boldsymbol{J}, \boldsymbol{K}, 20 \mu \mathrm{m}$. 


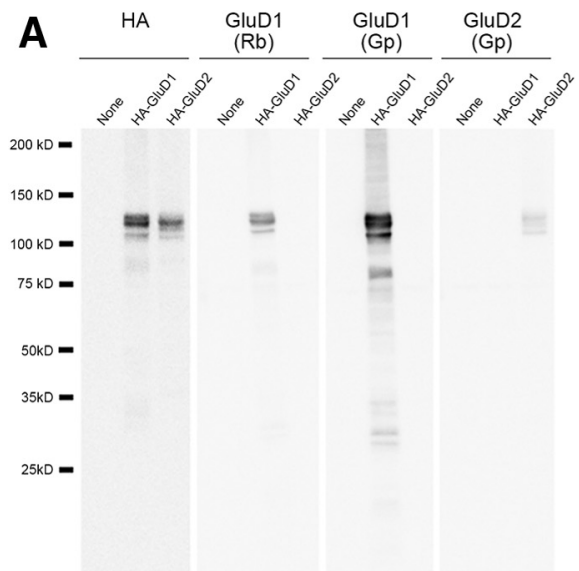

B

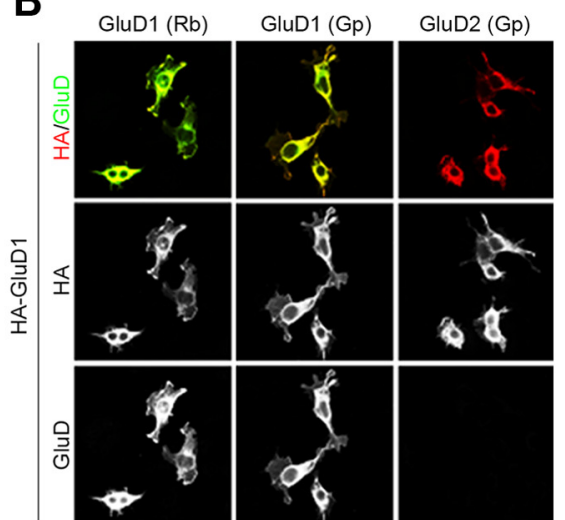

C

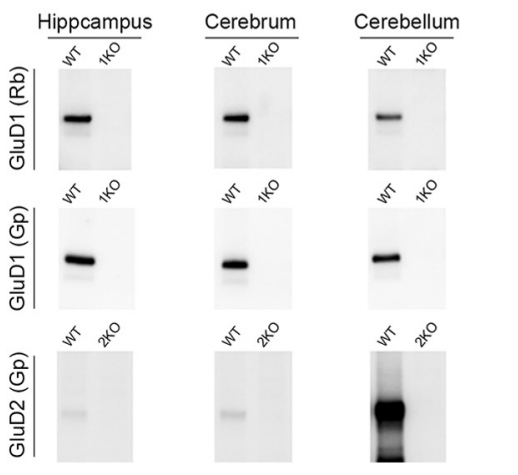

saline, pH 7.4 (TTBS)] for 10 min, blocking solution containing $2 \%$ normal goat serum (Nichirei) in TTBS for $10 \mathrm{~min}$, GluD1 or GluD2 antibody ( $20 \mu \mathrm{g} / \mathrm{ml}$ for each) diluted in $2 \%$ normal goat serum in TTBS overnight, and colloidal gold-conjugated $(10 \mathrm{~nm})$ anti-guinea pig IgG (1:100; British BioCell International) in blocking solution for $2 \mathrm{~h}$. For double labeling against VGluT2 and GluD1 or GluD2, sections were incubated in blocking solution containing $2 \%$ normal goat serum, followed by VGluT2 antibody $(20 \mu \mathrm{g} / \mathrm{ml})$ diluted in $2 \%$ normal goat serum in TTBS overnight and then colloidal gold-conjugated (15 nm) antirabbit IgG in blocking solution for $2 \mathrm{~h}$. After extensive washing in distilled water, sections were incubated in blocking solution containing 2\% rabbit serum (Nichirei) in TTBS for 10 min, GluD1 or GluD2 antibody diluted with $2 \%$ normal rabbit serum in TTBS overnight, and colloidal gold-conjugated $(10 \mathrm{~nm})$ antiguinea pig IgG in blocking solution for $2 \mathrm{~h}$. After extensive washing in distilled water, sections were fixed with $2 \%$ OsO4 for 15 min and then stained with $5 \%$ uranyl acetate $/ 40 \%$ EtOH for $90 \mathrm{~s}$ and Reynold's lead citrate solution for $60 \mathrm{~s}$. Photographs were taken from the molecular layer with the H-7100 electron microscope. For quantitative analysis, postsynaptic-membrane-associated immunogold particles, defined as those $<20 \mathrm{~nm}$ apart from the cell membrane, were counted on scanned electron micrographs and analyzed using MetaMorph software. Statistical significance was evaluated using the MannWhitney $U$ test. The vertical distribution of GluD1 was examined by sampling synaptic profiles with presynaptic and postsynaptic membranes that were cut perpendicularly to the plane of the synaptic cleft and measuring

ages were taken with a confocal laser-scanning microscope (FV1000; Olympus) equipped with a HeNe/Ar laser and PlanApo (10×/0.40), PlanApo $(20 \times / 0.70)$, and PlanApoN $(60 \times / 1.42$, oil-immersion) objective lenses (Olympus). To avoid cross talk between multiple fluorophores, Alexa Fluor 488, Cy3, and Alexa Fluor 647 fluorescent signals were acquired sequentially using the $488 \mathrm{~nm}, 543 \mathrm{~nm}$, and $633 \mathrm{~nm}$ excitation laser lines, respectively. All images show single optical sections $(640 \times$ 640 pixels).

To compare the density of molecular layer interneurons quantitatively, the number of parvalbumin-positive cells and the examined area were measured using MetaMorph software (Molecular Devices). Statistical significance was evaluated by a nonparametric Kruskal-Wallis test and a post hoc Mann-Whitney $U$ test with Bonferroni correction. Immunofluorescence intensity of GluD1 and GluD2 in the molecular layer was calculated by measuring the gray level and the area using images taken from lobules $4 / 5$ at the same gain level. Statistical significance was evaluated by Mann-Whitney $U$ test.

Electron microscopy. In conventional electron microscopy, ultrathin sections were stained with $2 \%$ uranyl acetate for $5 \mathrm{~min}$ and Reynold's lead citrate solution for $2 \mathrm{~min}$. Sampling fields were randomly chosen from the molecular layer and electron micrographs were taken at an original magnification of $3000 \times$ using an $\mathrm{H}-7100$ electron microscope (Hitachi). To compare the mean number of PF synapses on interneuron somata (PF-InS) per $1 \mu \mathrm{m}$ of somatic membrane quantitatively, somatic membrane of interneuron was measured using MetaMorph software (Molecular Devices). Statistical significance was evaluated by Kruskal-Wallis test and post hoc Mann-Whitney $U$ test with Bonferroni correction.

For postembedding immunogold electron microscopy, ultrathin sections on nickel grids were treated with successive solutions, as follows: 50 $\mathrm{mm}$ glycine in incubation solution $[0.01 \%$ Triton X-100 in Tris-buffered the distance from the midline of the synaptic cleft to the center of the immunogold particles.

\section{Results}

\section{GluD1mRNA expression in the brain}

We first examined regional and cellular expression of GluD1 mRNA in the adult mouse brain using in situ hybridization (Fig. 1). Use of a long antisense riboprobe and a long fixation protocol greatly enhanced the intensity of specific signals for GluD1 mRNA. Chromogenic in situ hybridization revealed higher levels in the olfactory bulb, hippocampus, cerebral cortex, striatum, and cerebellar cortex (Fig. 1A). In the hippocampus, GluD1 mRNA was intense in the pyramidal cell layer of the Ammon's horn, especially the CA2 subregion, and in the granule cell layer of the dentate gyrus (Fig. $1 B$ ). In the cerebellar cortex, cells expressing GluD1 mRNA were scattered in the molecular and granular layers (Fig. $1 H$ ). Specificity was ascertained by the lack of hybridizing signals using a sense riboprobe (Fig. $1 A$, inset).

Neurochemical properties of GluD1 mRNA-expressing neurons were examined in the hippocampus and cerebellar cortex by double-labeling FISH. In the hippocampus, GluD1 mRNA (Fig. $1 C-F$, red) was detected in pyramidal and granule cells expressing VGluT1 mRNA (Fig. 1C,D, green), and in GABAergic interneurons expressing GAD67 mRNA (Fig. 1E,F, green, arrows). The mean fluorescence intensity for GluD1 mRNA was calculated for each type of neuron and normalized to that in CA1 pyramidal cells (see Materials and Methods). The mean relative intensity 
was highest in CA2 pyramidal cells and lowest in hippocampal interneurons (Fig. $1 G)$. In the cerebellar cortex, GluD1 mRNA (Fig. $1 I-K$, red) was detected in GABAergic interneurons expressing GAD67 mRNA (Fig. 1I,J, green), including basket and stellate cells in the molecular layer and Golgi cells in the granular layer (Fig. 1I,J). Signals for GluD1 mRNA were very low in PCs (Fig. 1J, asterisks), and undetectable in granule cells expressing VGluT1 mRNA (Fig. $1 K)$. The intensity of fluorescent signals was measured and normalized to that in molecular layer interneurons. The mean relative intensity varied greatly from the highest level in molecular layer interneurons to the lowest or background level in granule cells (Fig. $1 L$ ). Therefore, GluD1 is widely expressed in the adult mouse brain, but its transcription levels are variable according to neuron type.

Production of specific GluD antibodies In the present study, we produced GluD1 and GluD2 antibodies against the corresponding C-terminal regions with low sequence homology. Immunoblotting experiments showed that rabbit and guinea pig GluD1 antibodies selectively recognized multiple protein bands at $110-130 \mathrm{kDa}$ in HEK293 cells transfected with HA-tagged GluD1 cDNA, but not GluD2 cDNA (Fig. 2A). Likewise, guinea pig GluD2 antibody selectively recognized protein bands at similar molecular masses in HEK293 cells transfected with HA-tagged GluD2 cDNA, but not GluD1 cDNA (Fig. 2A). These GluD1 and GluD2 antibodies yielded selective immunocytochemical labeling for HEK293 cells transfected with HA-tagged GluD1 or GluD2 cDNA, respectively (Fig. 2B).

The specificity was further tested by immunoblot using homogenates prepared from the hippocampus, cerebral cortex, and cerebellum of wild-type, GluD1-KO, and GluD2-KO mice (Fig. $2 C)$. In each brain region, rabbit and guinea pig GluD1 antibodies recognized protein bands in wild-type mice, but not GluD1-KO mice. Likewise, guinea pig GluD2 antibody recognized specific protein bands in all three brain regions of wild-type mice, but not in GluD2-KO mice. Of note, low levels of GluD2 were observed in the hippocampus and cerebral cortex in addition to the cerebellum. Therefore, these GluD antibodies are sensitive and specific to respective GluDs.

\section{GluD1 distribution in the brain}

In conventional immunofluorescence using 4\% PFA-perfused brain sections, the intensity of GluD1 immunolabeling was low (data not shown). When using fresh-frozen sections, GluD1 staining was markedly intensified all over the brains of wild-type mice (Fig. $3 A$ ). GluD1 immunoreactivity was distributed widely, with higher levels in the hippocampus, cerebral cortex, striatum, and cerebellar
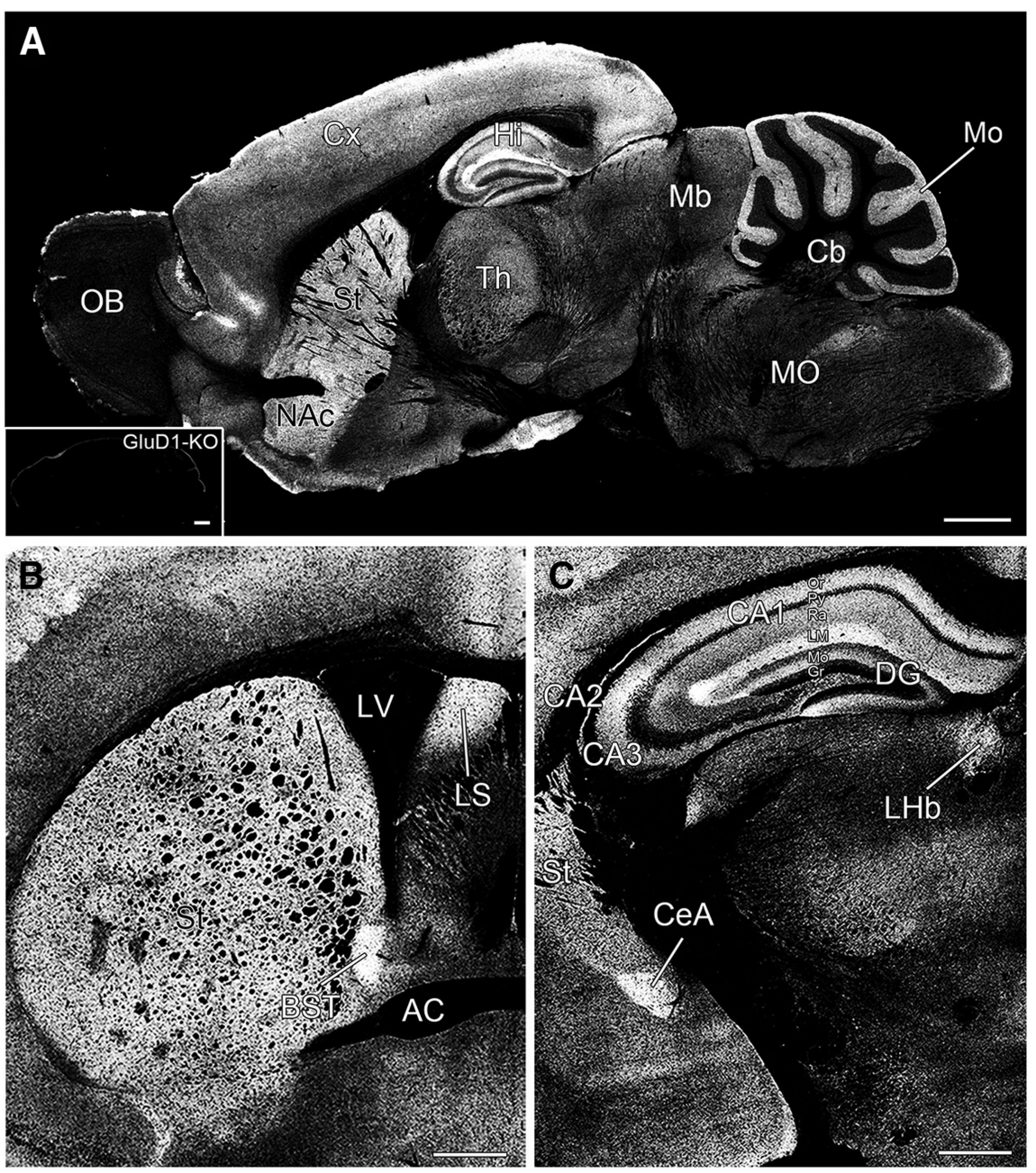

Figure 3. Immunofluorescence for GluD1 showing wide but distinct regional distribution in sagittal $(\boldsymbol{A})$ and coronal $(B, C)$ sections of adult mouse brain. Higher levels were detected in the cortex $(\boldsymbol{A}, \mathrm{CX})$, striatum $(\boldsymbol{A}-\boldsymbol{C}, \mathrm{St})$, nucleus accumbens $(\boldsymbol{A}, \mathrm{NAC})$ midbrain; M0, medulla oblongata; OB, olfactory bulb; Or, stratum oriens; Py, pyramidal cell layer; Ra, stratum radiatum; Th, thalamus. Scale bars: $A, 1 \mathrm{~mm} ; \boldsymbol{B}, \boldsymbol{C}, 500 \mu \mathrm{m}$.

cortex (Fig. 3A). GluD1 was generally low in the brainstem. These protein expression patterns are consistent with the mRNA expression patterns (Fig. 1A). The absence of immunostaining in GluD1-KO mouse brains (Fig. $3 A$, inset) verified the specificity of GluD1 immunohistochemistry, including the lack of cross reactivity to GluD2.

Using coronal brain sections, regional distribution of GluD1 was investigated in detail. Laminar distribution was remarkable in the hippocampus (Fig. 3C). GluD1 was enriched in the stratum lacunosum-moleculare of the Ammon's horn, particularly the CA2 subregion, and also in the middle molecular layer of dentate gyrus (Fig. 3C), suggesting input-pathway-dependent regulation of GluD1 expression. In addition to the hippocampus, intense signals were also seen in other limbic regions, including the nucleus accumbens (Fig. 3A), lateral septum (Fig. 3B), bed nucleus stria terminalis (Fig. $3 B$ ), and central nucleus of the amygdala (Fig. $3 C$ ).

Selective expression of GluD1 at PF-interneuron synapses GluD2 has been shown to accumulate in the cerebellar molecular layer, where it is high at PF synapses on PC spines and 

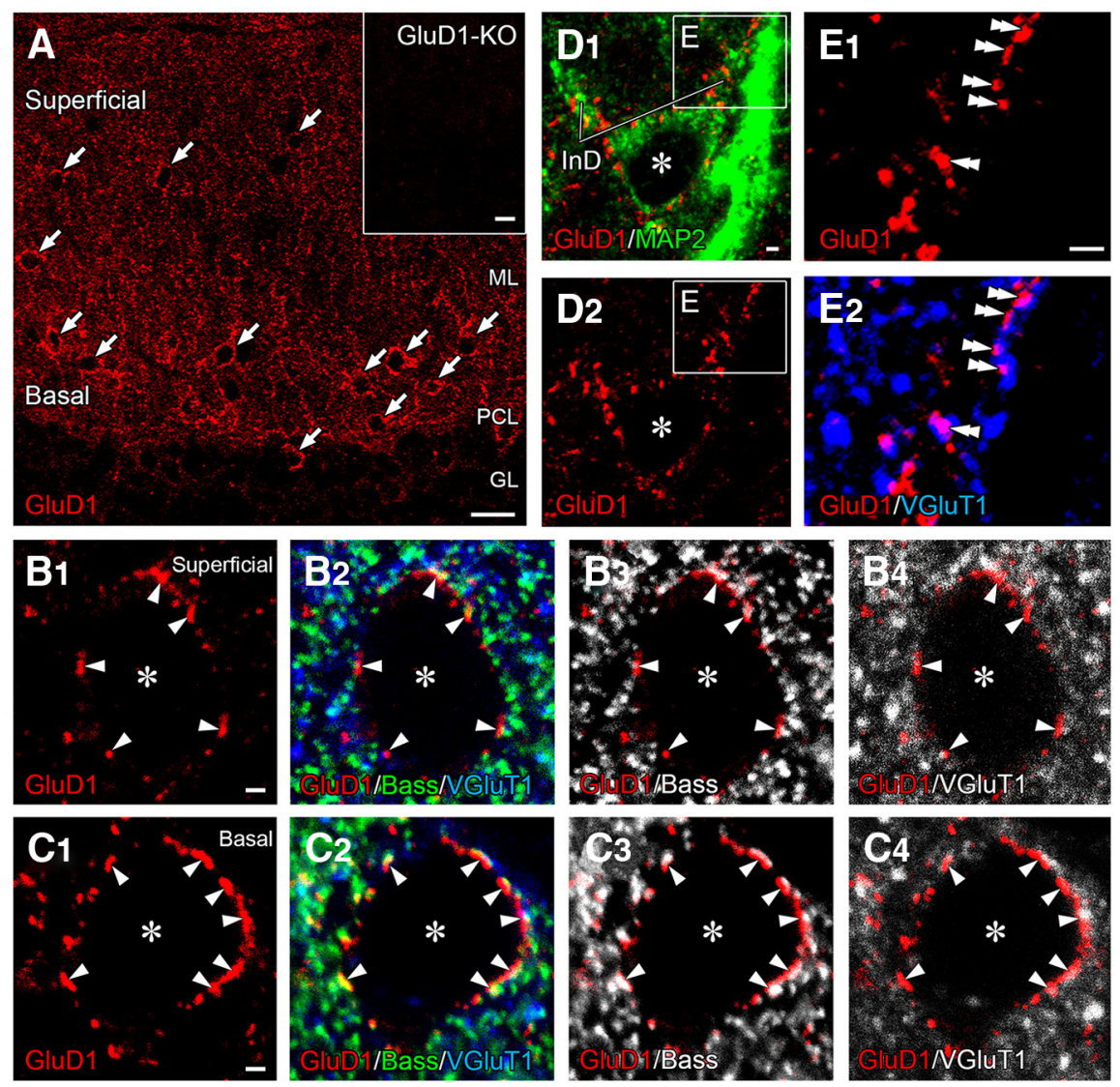

Figure 4. GluD1 forms clusters around PF synapses on somata and dendrites of molecular layer interneurons. $\boldsymbol{A}$, Immunofluorescence for GluD1 in the cerebellar cortex. Note a prominent perisomatic basket formation around interneuron somata in both the superficial and basal portions of the molecular layer. Inset shows negative staining in the cerebellar cortex of a GluD1-K0 mouse. $\boldsymbol{B}$, C, Triple immunofluorescence for GluD1 (red), bassoon (green), and vesicular glutamate transporter 1 (VGluT1, blue) in the superficial $(\boldsymbol{B})$ and basal $(\boldsymbol{C})$ molecular layer. Arrowheads indicate GluD1 clusters that are closely apposed to bassoon-positive/ VGluT1-positive PF terminals. D, E, Triple immunofluorescence for GluD1 (red), MAP2 (green), and VGluT1 (blue) in the basal molecular layer. Double arrowheads indicate GluD1 clusters that are apposed to both MAP2-positive interneuron dendrites and VGluT1-positive PF terminals. Scale bars: $\boldsymbol{A}, 20 \mu \mathrm{m} ; \boldsymbol{B}-\boldsymbol{E}, 1 \mu \mathrm{m}$.

weak at PF synapses on interneuron dendrites (Takayama et al., 1996; Landsend et al., 1997; Yamasaki et al., 2011). In the present study, we selected this region for detailed analysis of synaptic localization of GluD1.

Immunofluorescence for GluD1 exhibited preferential interneuron labeling in the molecular layer, showing a basal-tosuperficial gradient of immunofluorescence intensity (Fig. 4A, arrows). This staining was not detected in GluD1-KO mice (Fig. $4 A$, inset), indicating the specificity of the interneuron labeling. At high magnifications, GluD1 formed basket-like clustering around somata of molecular layer interneurons. To determine whether perisomatic clusters of GluD1 were associated with particular synapses, we applied triple immunofluorescence for GluD1 (Fig. $4 B, C$, red), presynaptic active zone protein bassoon (Fig. $4 B, C$, green), and PF terminal marker VGluT1 (Fig. $4 B, C$, blue). In both the superficial (Fig. $4 B$ ) and basal (Fig. 4C) molecular layer, where stellate and basket cells reside, respectively $(\mathrm{Pa}-$ lay and Chan-Palay, 1974), perisomatic clusters of GluD1 were apposed to bassoon-positive/VGluT1-positive PF terminals, with GluD1 being always located inside these terminals (Fig. 4B, $C$, arrowheads). PF synapse-associated clustering was also true for GluD1-positive puncta in the neuropil because they were distributed around MAP2-positive dendrites of molecular layer interneurons (Fig. 4D, green) and apposed to VGluT1-positive PF terminals (Fig. 4E, blue). These results suggest that GluD1 accumulates at PF synapses on somata and dendrites of molecular layer interneurons.

\section{Reciprocal distribution of GluD1 and GluD2 among PF synapses}

To confirm GluD1 expression at PF-interneuron synapses and to compare it quantitatively with expression of GluD2, postembedding immunogold electron microscopy was applied to the molecular layer. Immunogold particles for GluD1 often fell on the postsynaptic membrane at PF-InS synapse, which were defined as asymmetrical synapses between small round terminals and interneuron somata (Fig. 5A). Compared with PF-InS synapses, immunogold labeling was less frequent at $\mathrm{PF}$ synapses on interneuron dendrites (PF-InD synapse), which were defined as asymmetrical synapses on aspiny dendrites (Fig. 5B). The postsynaptic membrane at the corresponding synapses in GluD1-KO mice was rarely labeled (Fig. $5 A, B$, insets). The density of immunogold labeling per $1 \mu \mathrm{m}$ of the postsynaptic membrane was significantly higher at PF-InS and PF-InD synapses in wild-type mice than the background level, as determined from the corresponding synapses in GluD1-KO mice $(p<0.001$, 0.01 , or 0.05 , respectively, Mann-Whitney $U$ test; Fig. $5 E$ ). Moreover, the density of immunogold labeling was apparently higher at PF-InS synapses than at PF-InD synapses in both the basal and superficial molecular layer of wild-type mice, although statistical significance was noted in the basal molecular layer only $(p<0.001$; Fig. $5 E)$. No significant labeling for GluD1 was found at PF-PC synapses and climbing fiber (CF)-PC synapses (Fig. 5C-E); the latter synapses were identified as asymmetrical synapses between VGluT2-labeled CF terminals and dendritic spines (Fig. 5D). We also examined the vertical distribution of GluD1 at PF-InS synapses by measuring the distance from the midline of the synaptic cleft to the center of immunogold particles in the basal molecular layer of wildtype mice ( $n=114$ particles, two mice). The distribution of immunogold particles peaked in a +10 to $+20 \mathrm{~nm}$ bin, with the mean distance of $12.20 \pm 1.73 \mathrm{~nm}$ postsynaptic from the midline of the synaptic cleft (Fig. 5F). This value, obtained at PF-InS synapses using GluD1 antibody against the C-terminus, was almost equivalent to that obtained at PF-PC synapses using GluD2 antibody against the C-terminus (10.49 $\pm 27.20 \mathrm{~nm}$; Miura et al., 2009). Therefore, GluD1 is expressed highly at postsynaptic sites of PF-InS synapses and weakly at PF-InD synapses.

In contrast, synaptic labeling for GluD2 was overwhelming at PF-PC synapses $(p<0.001$; Fig. $6 C, E)$ and was also detected at a much lower level at PF-InD synapses $(p<0.001$; Fig. $6 B, E)$. However, no significant labeling was observed at PF-InS synapses (Fig. 6A,E) or CF-PC synapses (Fig. 6D,E). Therefore, 

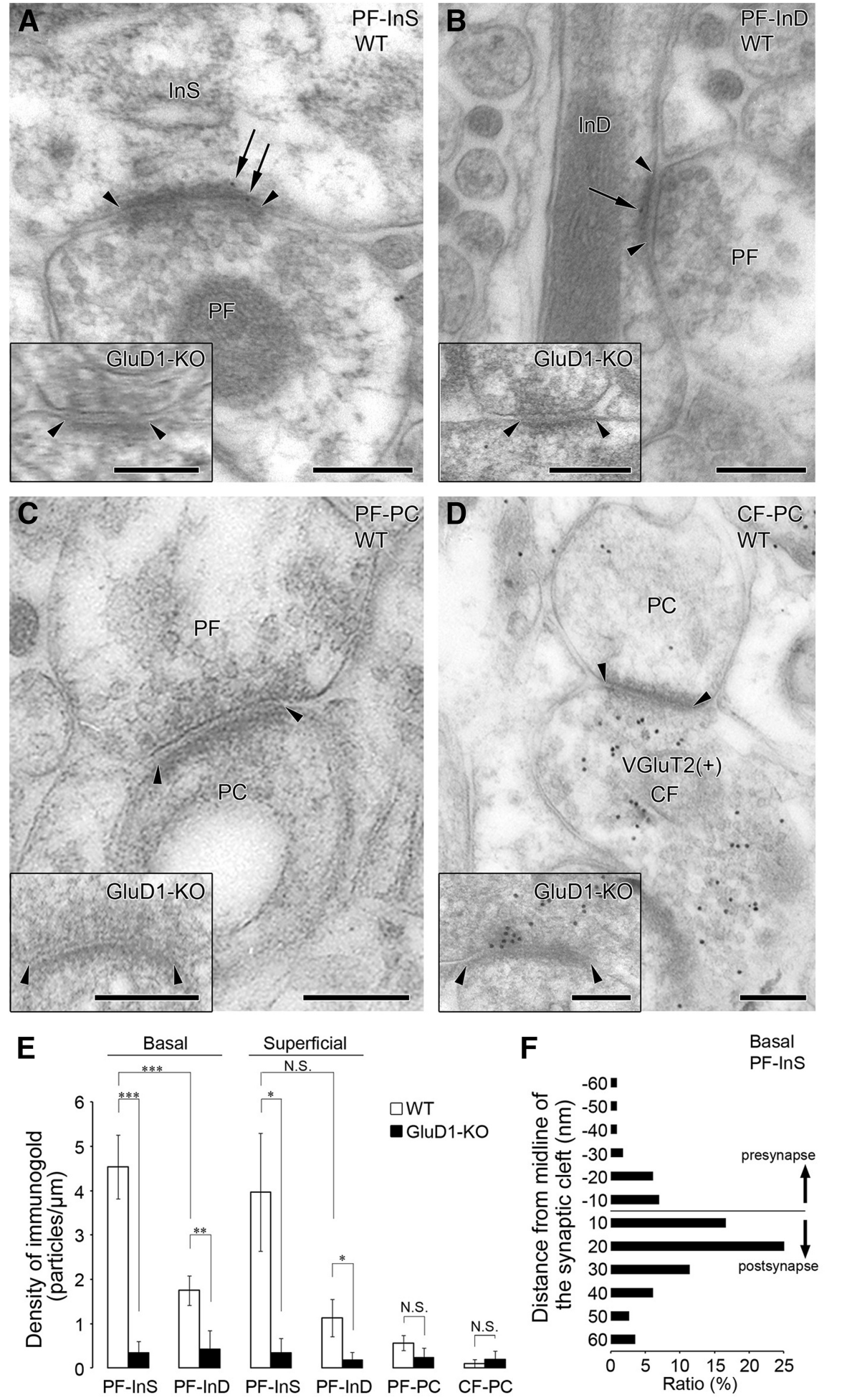

Figure 5. Postembedding immunogold electron microscopy for GluD1 in the cerebellar molecular layer. $\boldsymbol{A}-\boldsymbol{C}$, Single-labeling postembedding immunogold for GluD1 $(\varphi=10 \mathrm{~nm})$ at a PF-InS synapse $(\boldsymbol{A})$, a PF-InD synapse $(\boldsymbol{B})$, and a PF-PC synapse (C). $\boldsymbol{D}$, Double-labeling postembedding immunogold for GluD1 $(\varphi=10 \mathrm{~nm})$ and VGluT2 $(\varphi=15 \mathrm{~nm})$ at a CF-PC synapse. Insets in $\boldsymbol{A}-\boldsymbol{D}$ indicate negative labeling at the corresponding synapses in GluD1-KO mice. Arrows and arrowheads indicate immunogold labeling or the edge of the PSD, respectively. $\boldsymbol{E}$, Histogram showing the mean density of immunogold particles for GluD1 (per $1 \mu \mathrm{m}$ of the postsynaptic membrane). The density was $4.53 \pm 0.72(n=71$, basal) at PF-InS synapses, $1.75 \pm 0.33$ ( $n=89$, basal) at PF-InD synapses, $3.96 \pm 1.33(n=26$, superficial) at PF-InS synapses, $1.13 \pm 0.42(n=41$, superficial) at PF-InD synapses, $0.56 \pm$ 0.17 at PF-PC synapses $(n=89)$, and $0.10 \pm 0.10(n=34)$ at CF-PC synapses of wild-type mice. In GluD1-K0 mice, the density was $0.35 \pm 0.25(n=36$, basal) at PF-InS synapses, $0.42 \pm 0.42(n=36$, basal) at PF-InD synapses, $0.34 \pm 0.34(n=15$, superficial) at PF-InS synapses, $0.18 \pm 0.18(n=20$, superficial) at PF-InD synapses, $0.23 \pm 0.23$ at PF-PC synapses $(n=22)$, and $0.19 \pm 0.19(n=20)$ at CF-PC synapses. Bars on each column represent SEM. ${ }^{* * *} p<0.001 ;{ }^{* *} p<0.01 ;{ }^{*} p<0.05$;
GluD1 and GluD2 are selective to PF synapses and are expressed reciprocally among the three kinds of PF synapses.

\section{Opposing changes in PF-InS synapse density in GluD1-KO and GluK2-KO mice}

GluD2 strengthens the connectivity of PF-PC synapses, and the ablation of the Grid2 gene in mice results in reduced PF-PC synapse number per PC to half the level found in wild-type mice (Kashiwabuchi et al., 1995; Kurihara et al., 1997). To address whether GluD1 plays a similar role, we analyzed PF-InS synapses in wild-type, GluD1-KO, and GluD2-KO mice by triple immunofluorescence for bassoon (green), VGluT1 (red), and parvalbumin (blue; Fig. $7 A-C$ ). Although parvalbumin is expressed in both interneurons and PCs, they are readily distinguished by the size and location of somata (Fig. $8 A-C$ ). In wild-type mice, parvalbumin-positive somata of molecular layer interneurons were frequently contacted by bassoon-positive/VGluT1positive PF terminals (Fig. $7 A$, arrowheads). Such PF terminals attaching to interneuron somata were apparently reduced in GluD1-KO mice (Fig. 7B) but increased in GluD2-KO mice (Fig. 7C).

To quantify this difference, the number of PF-InS synapses on somatic profiles of molecular layer interneurons was counted by conventional electron microscopy (Fig. $7 D-G$ ). The mean number of PF-InS synapses per $1 \mu \mathrm{m}$ of somatic membrane was reduced by $47 \%$ in GluD1-KO mice (Fig. $7 E, G$ ) and increased by $60 \%$ in GluD2-KO mice (Fig. $7 F, G)$ compared with wild-type mice (Fig. $7 D, G$ ). A Kruskal-Wallis test revealed a significant effect of group ( $p<$ 0.001). A post hoc test using Mann-Whitney $U$ test with Bonferroni correction showed significant differences between wild-type and GluD1-KO mice $(p<$ $0.001)$ or GluD2-KO mice $(p<0.001)$ (Fig. $7 G$ ). Therefore, the density of PFInS synapses is altered in opposite directions in GluD1-KO and GluD2-KO mice compared with wild-type mice.

N.S. not significant; Mann-Whitney $U$ test. $\boldsymbol{F}$, Histogram showing the vertical distribution of GluD1 epitope at PF-InS synapses sampled from the basal molecular layer. The distance was measured from the midline of the synaptic cleft to the center of immunogold particles ( $n=114$ particles from two C57BL/6 mice). On the $x$-axis, - and + represent presynaptic or postsynaptic side, respectively, from the midline of the synaptic cleft. Sp, Spine. Scale bars, $200 \mathrm{~nm}$. 

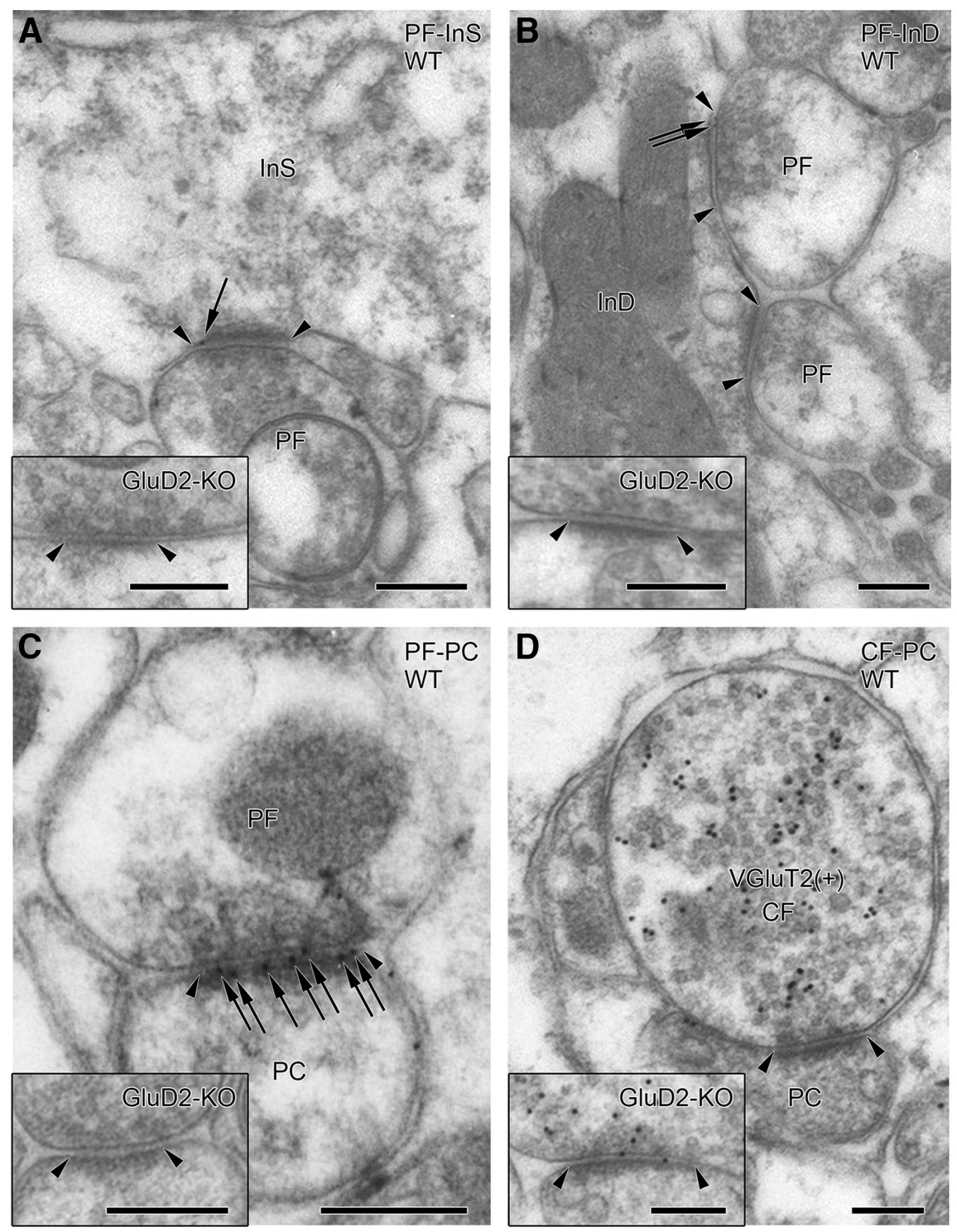

E

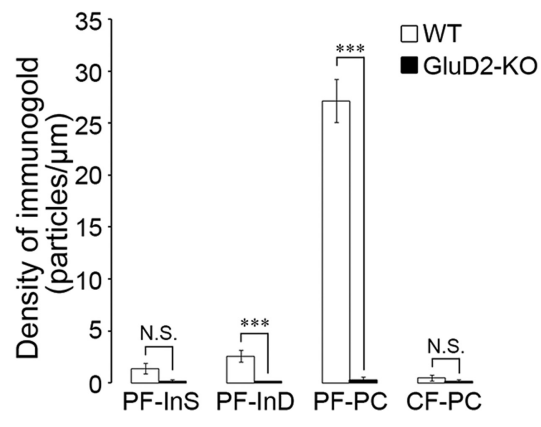

Figure 6. Postembedding immunogold electron microscopy for GluD2 in the cerebellar molecular layer. $\boldsymbol{A}-\boldsymbol{D}$, See legends for Figure 5A-D.E, Histogram showing the mean density of immunogold particles for GluD2 (per $1 \mu \mathrm{m}$ of the synaptic membrane). The density was $1.37 \pm 0.50(n=34)$ at PF-InS synapses, $2.59 \pm 0.58(n=44)$ at PF-InD synapses, $27.15 \pm 2.09$ at PF-PC synapses $(n=39)$, and $0.49 \pm 0.27(n=26)$ at CF-PC synapses of wild-type mice. In GluD2-K0 mice, the density was $0.16 \pm 0.16(n=25)$ at PF-InS synapses, $0.12 \pm 0.12(n=30)$ at PF-InD synapses, $0.30 \pm 0.30$ at PF-PC synapses $(n=24)$, and $0.16 \pm 0.16(n=17)$ at CF-PC synapse. Bars on each column represent SEM. ${ }^{* *} p<$ 0.001 ; N.S. not significant; Mann-Whitney U test. Sp, Spine. Scale bars: $200 \mathrm{~nm}$.

\section{Opposing changes in interneuron density in GluD1-KO and GluD2-KO mice}

In addition, we noticed alterations in the number of parvalbumin-positive interneurons in the molecular layer. Compared with wild-type mice, parvalbuminpositive interneurons appeared to be scarce in GluD1-KO mice but numerous in GluD2-KO mice (Fig. 8A-C). The density of parvalbumin-positive interneurons in the molecular layer was significantly reduced by $35 \%$ in GluD1-KO mice and increased by $76 \%$ in GluD2-KO mice compared with wild-type mice (KruskalWallis test, $p<0.001$; Mann-Whitney $U$ test with Bonferroni correction, $p<0.001$ for each; Fig. $8 D$ ). This opposing change did not result merely from downregulation or upregulation of parvalbumin expression because the number of GAD67 mRNA-expressing interneurons was also changed in parallel with parvalbuminpositive interneurons (Fig. $8 F-H$ ).

We further noted diminished somatic size of interneurons in GluD1-KO mice (Fig. $8 B$ ). Compared with wild-type mice, the mean somatic area of parvalbuminpositive interneurons was significantly reduced by $24 \%$ in GluD1-KO mice (Kruskal-Wallis test, $p<0.001$; post hoc test using Mann-Whitney $U$ test with Bonferroni correction, $p<0.001$; Fig. $8 E$ ), whereas no significant difference was found in GluD2-KO mice (Mann-Whitney $U$ test with Bonferroni correction, $p>0.05$; Fig. $8 E$ ). These results suggest that GluD1 promotes the differentiation and/or survival of molecular layer interneurons, whereas GluD2 counteracts this phenomenally.

\section{Compensatory upregulation of GluD1 in GluD2-KO mice}

To understand the opposing changes by the ablation of GluD1 and GluD2, we pursued possible compensatory changes of one GluD expression in mutant mice lacking another GluD. In GluD2-KO mice, GluD1 labeling was clearly enhanced on somata and dendrites of molecular layer interneurons; this enhancement was confirmed in all three pairs of wild-type and GluD2-KO mice (Fig. 9A,B). By measuring the intensity of immunofluorescence signals in the molecular layer, the mean intensity for GluD1 was significantly increased by $54 \%$ in GluD2-KO mice compared with wild-type mice $(p<0.001$, Mann-Whitney $U$ test; Fig. $9 E$, left). In contrast, no significant upregulation or downregulation was discerned for GluD2 in the molecular layer of GluD1-KO mice $(p>0.05$; Fig. $9 C, D, 9 E$, right). 
This immunohistochemical finding was in parallel with immunoblot data using cerebellar samples prepared from wild-type, GluD1-KO, and GluD2-KO cerebella (Fig. 9F). The intensity of GluD1 bands in GluD2-KO cerebella was significantly elevated in the homogenate (by $48 \%$ compared with wild-type cerebella; $p<0.01$, Student's $t$ test with Welch's correction, $n=3$ ), synaptosome fraction (by $64 \% ; p<0.01$ ), and PSD fraction (by $79 \%$; $p<0.001$; Fig. $9 G$, top). No significant increase or decrease was found for GluD2 bands in any cerebellar samples prepared from GluD1-KO cerebella $(p>$ 0.05 for each, $n=3$; Fig. $9 G$, bottom). Therefore, ablation of the Grid2 gene in mice significantly upregulates GluD1 expression in molecular layer interneurons.

\section{Discussion}

Although cellular and synaptic expressions of GluD2 and its regulatory mechanisms for synaptic development and plasticity have been well characterized (Yuzaki, 2009; Watanabe and Kano, 2011), those for GluD1 remain largely elusive. In the present study, we investigated this issue using expression analyses on GluD1 and neuroanatomical analyses on the cerebellar molecular layer of GluD1-KO mice. Here, we have demonstrated that GluD1 is distinct from GluD2 in regional, neuronal, and synaptic expressions in adult mouse brains and that specific types of synapses and neurons expressing GluD1 are significantly lost in GluD1-KO mice.

Enriched expression of GluD1 in higher brain regions

Using in situ hybridization with a radiolabeled oligonucleotide probe, Lomeli et al. (1993) first reported low and diffuse expression of GluD1 mRNA in adult rat brains, with the highest level in the hippocampus and transient elevation at neonatal stages. In the present study, we developed histochemical probes that can detect GluD1 mRNA and immunoreactivity with high sensitivity and specificity. As a result, GluD1 expression was clearly shown to be widespread in the adult mouse brain, with higher levels in the cerebral cortex, striatum, cerebellar cortex, and many regions of the limbic system, including the hippocampus, nucleus accumbens, lateral septum, bed nucleus stria terminalis, lateral habenula, and central nucleus of the amygdala.

The significance of GluD1 in a variety of brain functions has been inferred from animal and human studies. Aberrant
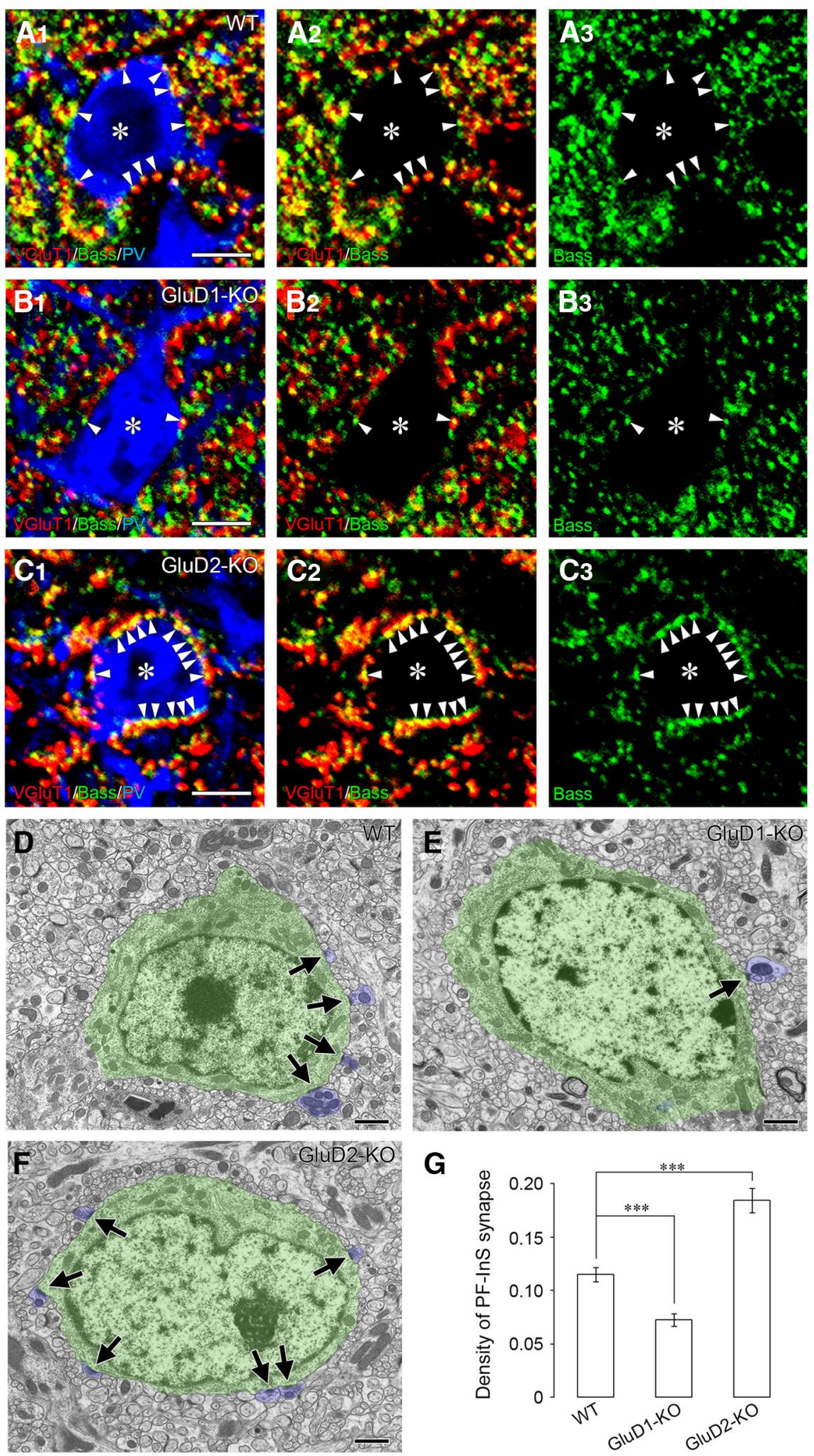

Figure 7. Opposing changes in the density of PF synapses on interneuron somata in GluD1-KO and GluD2-K0 mice. $\boldsymbol{A}-\boldsymbol{C}$, Triple immunofluorescence for VGluT1 (red), bassoon (green), and parvalbumin (blue) in wild-type (A), GluD1-K0 (B), and GluD2-K0 mice (C). Arrowheads indicate VGluT1(+)/bassoon $(+)$ puncta around parvalbumin $(+)$ interneuron somata. $\boldsymbol{D}-\boldsymbol{F}$, Electron microscopic images of somata of molecular layer interneurons in wild-type (D), GluD1-KO (E), and GluD2-K0 mice (F). Arrows indicate PF-InS synapses formed between interneuron somata (pseudocolored in green) and PF terminals (blue). G, Histogram showing the mean density of asymmetrical synapses on interneuron somata (per $1 \mu \mathrm{m}$ of somatic membrane): $0.12 \pm 0.01$ synapses $(n=$ 54 cells) in wild-type, $0.06 \pm 0.01(n=40)$ in GluD1-K0, and $0.18 \pm 0.01(n=67)$ in GluD2-K0 mice. Bars on each column represent SEM. ${ }^{* * *} p<0.001$, Mann-Whitney $U$ test. Scale bars: $\boldsymbol{A}-\boldsymbol{C}, 5 \mu \mathrm{m} ; \boldsymbol{D}-\boldsymbol{F}, 1 \mu \mathrm{m}$. 

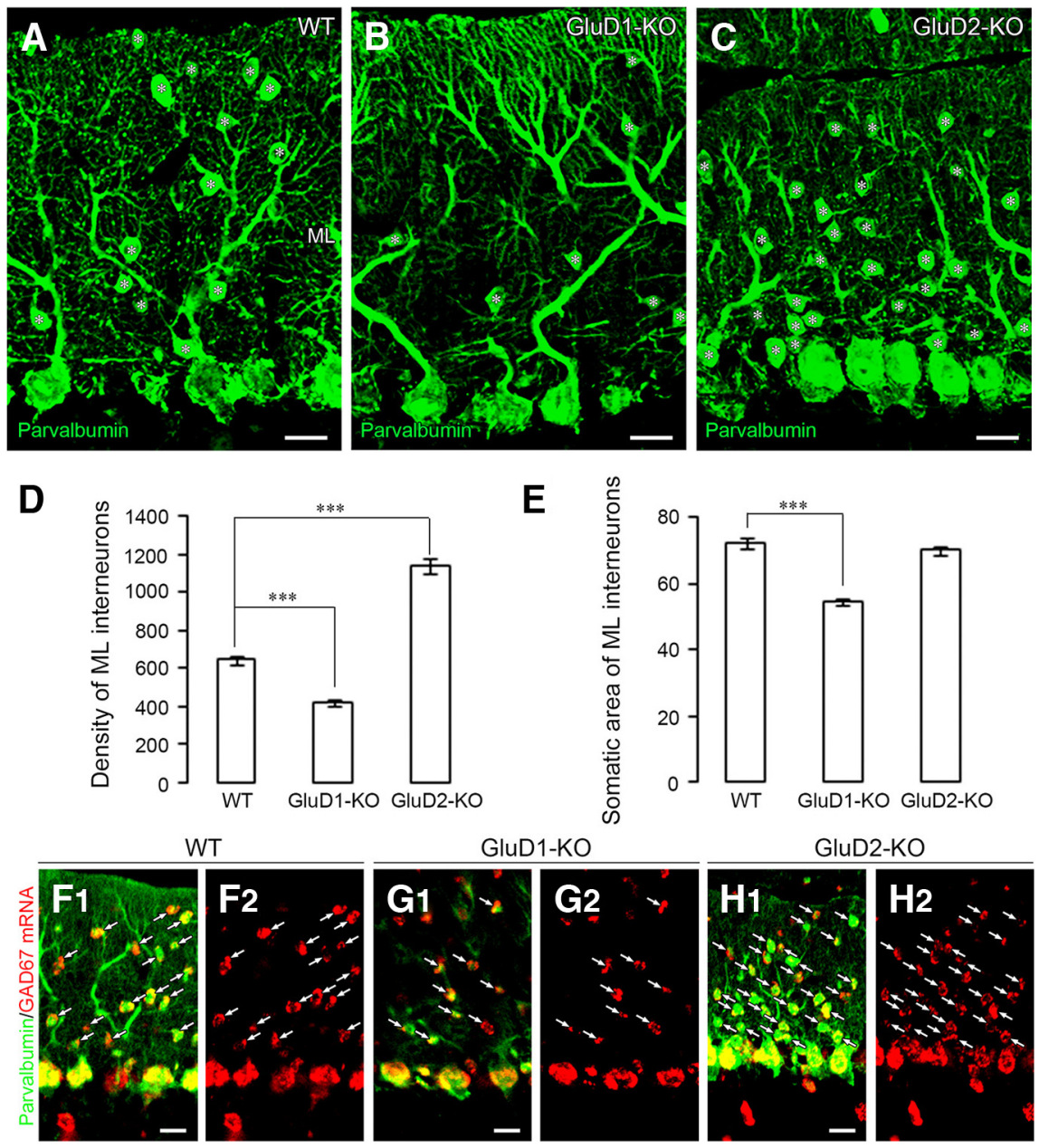

Figure 8. Opposing changes in the density of molecular layer interneurons between GluD1-K0 and GluD2-K0 mice and reduced somatic size in GluD1-K0 mice. $\boldsymbol{A}$ - $\boldsymbol{C}$, Immunofluorescence for parvalbumin in the cerebellar cortex of wild-type $(\boldsymbol{A})$, GluD1-KO $(\boldsymbol{B})$, and GluD2-KO mice ( $\boldsymbol{C}$. Asterisks indicate the soma of molecular layer interneurons. $\boldsymbol{D}$, Histogram showing the mean density of parvalbumin-positive interneurons: $646.0 \pm 24.3$ cells $/ \mathrm{mm}^{2}$ (measured area, $1.36 \mathrm{~mm}^{2}$ ) in wild-type, $423.0 \pm 16.6(1.59)$ in GluD1-K0, and $1138.1 \pm 42.8(0.93)$ in GluD2-KO mice. $\boldsymbol{E}$, Histogram showing the mean somatic area of parvalbumin-positive interneurons: $72.1 \pm 1.7 \mu \mathrm{m}^{2}(n=109$ cells) in wild-type, $54.5 \pm 1.1$ (129) in GluD1-K0, and 70.2 $\pm 1.3(n=138)$ in GluD2-K0 mice. Bars on each column represent SEM. ${ }^{* * *} p<0.001$, Mann-Whitney $U$ test. $\boldsymbol{F}-\boldsymbol{H}$, Immunofluorescence for parvalbumin (green) combined with FISH for GAD67 mRNA (red) in wild-type $(\boldsymbol{F})$, GluD1-KO $(\boldsymbol{G})$, and GluD2-K0 mice $(\boldsymbol{H})$. Arrows indicate molecular layer interneurons. Scale bars, $20 \mu \mathrm{m}$.

emotional and social behaviors have been documented in GluD1-KO mice, including higher spontaneous locomotor activity in the open-field test, lower anxiety-like behavior in the elevated plus maze test, depression-like behavior in the forced swim test, robust aggression in the resident-intruder test, and deficits in the social interaction test (Yadav et al., 2012). The mice also manifest enhanced working memory and deficits in the fear conditioning test (Yadav et al., 2013). Human genome-wide association and copy number variation studies identified the GRID1 gene, which codes for GluD1, as a strong candidate gene for schizophrenia, bipolar disorder, major depressive disorder, and autism spectrum disorder (Fallin et al., 2005; Guo et al., 2007; Glessner et al., 2009; Smith et al., 2009; Treutlein et al., 2009; Cooper et al., 2011; Greenwood et al., 2011; Edwards et al., 2012; Griswold et al., 2012). Importantly, neural regions with rich GluD1 expression are the neural centers for cognition, memory and learning, emotion, voluntary movement, and motivation and rewarding. Therefore, detailed expression and phenotypic analyses in these higher brain regions are expected to provide important insights toward understanding the role of GluD1 in neural development and function.
GluD2-KO

Distinct synaptic targeting of GluD1

We selected the cerebellar molecular layer for the present analysis because this region has been best studied for synaptic expression and functional role of GluD2. In this region, GluD1 was enriched at PF synapses in the following order: PF-InS synapse $>$ PF-InD synapse $\gg$ PF-PC synapse. This distribution was distinct from that of GluD2, which was expressed in the following order: $\mathrm{PF}-\mathrm{PC}$ synapse $\gg$ PF-InD synapse $>$ PF-InS synapse (Takayama et al., 1996; Landsend et al., 1997; Yamasaki et al., 2011; present study). In contrast, CF-PC synapses were at the background level for both GluD1 and GluD2. These expression properties indicate that GluD1 and GluD2 are similar in that they are selective to PF synapses in the cerebellar molecular layer, but their synaptic targeting is reciprocally regulated in target cell- and target site-dependent manners. Perisomatic baskets are formed around GABAergic molecular layer interneurons by excitatory PF terminals (Palay and Chan-Palay, 1974; Zanjani et al., 2006) and GluD1 was most enriched at PF-InS synapses forming this pericellular basket. This molecular-anatomical configuration is in a sharp contrast with that in the cortex and hippocampus, where perisomatic baskets are formed around glutamatergic principal neurons by terminals of inhibitory interneurons (Freund, 2003). This suggests that synaptic targeting of GluD1 is strategically controlled to construct distinct synaptic organization in specific brain regions and neurons.

Because previous studies have highlighted exclusive expression of GluD2 in the cerebellar cortex (Araki et al., 1993; Lomeli et al., 1993; Yamasaki et al., 2011), low but specific detection of GluD2 in the cortex and hippocampus was an unexpected finding in the present study. Recently, biallelic deletions of GRID2 gene have been identified in human families with severe cerebellar atrophy and symptoms (Hills et al., 2013; Utine et al., 2013). It is interesting to note that all of the affected individuals also showed delay in speech and cognitive development, implying the role of GluD2 in the cerebral cortex (Hills et al., 2013). Therefore, it is important in future studies to clarify how synaptic targeting of GluD1 and GluD2 is regulated in extracerebellar regions.

\section{GluD1 strengthens synaptic connectivity}

We found that the number of PF-InS synapses was significantly reduced by $47 \%$ in GluD1-KO mice, suggesting that GluD1 strengthens the connectivity of PF-InS synapses, as GluD2 does for PF-PC synapses (Kurihara et al., 1997; Takeuchi et al., 2005). It has been demonstrated that the connectivity of PF-PC synapses is mediated by binding of GluD2 on PC spines to neurexin on PF terminals via Cbln1 (Hirai et al., 2005; Ito-Ishida et al., 2008; Matsuda et al., 2010; Uemura et al., 2010). Cbln1 is produced and secreted from granule cells and accumulates in the 
synaptic cleft of PF synapses on PCs and molecular layer interneurons (Miura et al., 2009). Furthermore, Cbln1 also binds to GluD1 and their interaction induces synaptogenesis in in vitro experiments (Matsuda et al., 2010, Yasumura et al., 2012; Ryu et al., 2012). These findings suggest that GluD1 strengthens the connectivity of PF-InS synapses by interacting with Cbln 1 and neurexins. This possibility needs to be tested in future studies.

\section{GluD1 promotes survival and}

\section{differentiation of interneurons}

Another phenotype in GluD1-KO mice was a significant $(35 \%)$ loss of molecular layer interneurons. We speculate that this phenotype is secondary to reduced PFInS synapses for the following reasons.

Neurotrophin signaling, particularly that mediated by brain-derived neurotrophic factor (BDNF) and the BDNF receptor $\operatorname{TrkB}$, is indispensable for development of cerebellar interneurons (Lindholm et al., 1997; Schwartz et al., 1997; Carter et al., 2002). BDNF is highly expressed in granule cells, whereas highaffinity neurotrophin receptors are expressed in various cerebellar neurons, including molecular layer interneurons (Klein et al., 1990; Alvarez-Dolado et al., 1994; Gao et al., 1995; Segal et al., 1995; Benisty et al., 1998). BDNF is required for the survival, differentiation, and synaptogenesis of GABAergic interneurons in vitro (Mertz et al., 2000; Seil, 2003; Spatkowski and Schilling, 2003; Adcock et al., 2004) and ablation of the trkB gene in mice severely impairs synaptic differentiation in GABAergic interneurons (Rico et al., 2002). Therefore, we assume that GluD1mediated formation and/or maintenance of PF-InS synapses increases both excitatory drive and neurotrophic support to molecular layer interneurons, thereby promoting their differentiation and survival. The lack of compensatory upregulation of GluD2 further supports that these phenotypes in GluD1-KO mice are primarily due to the loss of GluD1.

In our previous study, no significant decrease or increase was observed for the density of PF-InD synapses in GluD2-KO mice (Yamasaki et al., 2011). Therefore, it was unexpected to find significant increase of PF-InS synapses by $60 \%$ in GluD2-KO mice here. We assume that this synaptic increase is explained, at least partly, by compensatory upregulation of GluD1 at interneuron somata in GluD2-KO mice. With respect to unaltered density of PDInD synapses in GluD2-KO mice (Yamasaki et al., 2011), compensatory upregulation at interneuron dendrites might also contribute to the maintenance of PD-InD synapses.

\section{Functional implications}

Molecular layer interneurons are the node of a feedforward inhibition from granule cells to PCs. This pathway is driven by PF activities and casts two modes of inhibition: GABAergic inhibition onto the soma and dendrites of PCs and electrical inhibition onto the axon initial segment of PCs (Korn and Axelrad, 1980;
GluD1
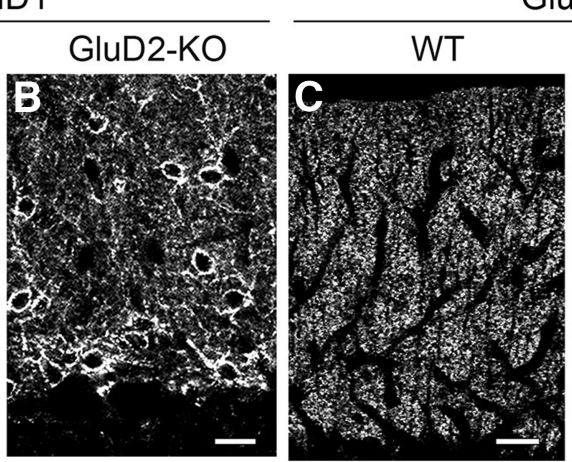

$\mathbf{F}$
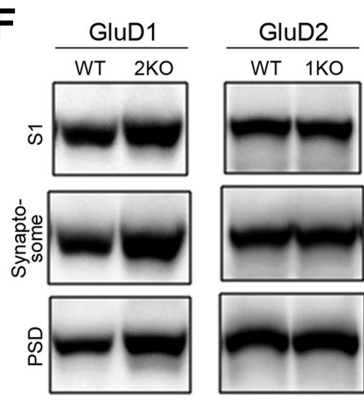

G

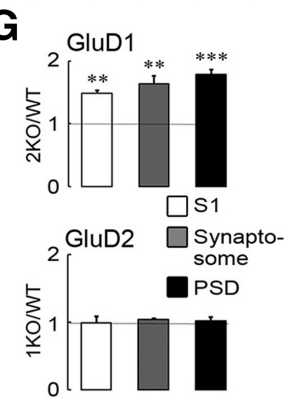

GluD2
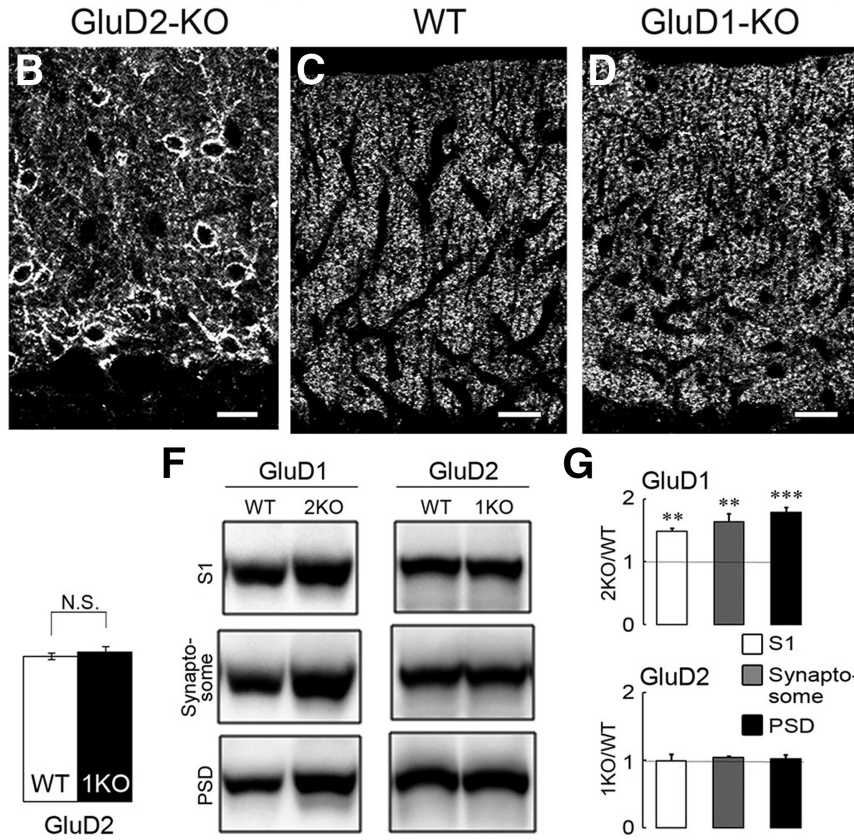

Figure 9. Upregulation of GluD1 in molecular layer interneurons of GluD2-K0 mice. $A-D$, Immunofluorescence for GluD1 $(A, B)$ and GluD2 $(\boldsymbol{C}, \boldsymbol{D})$ in wild-type $(\boldsymbol{A}, \boldsymbol{C})$, GluD2-KO $(\boldsymbol{B})$, and GluD1-KO (D) mice. $\boldsymbol{E}$, Histogram showing the mean fluorescence intensity

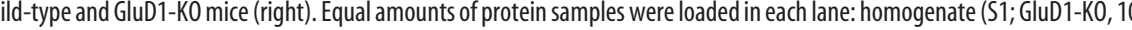
dent's $t$ test with Welch's correction (G). ${ }^{* *} p<0.001 ;{ }^{* *} p<0.01$; N.S., not significant. Bars on each column represent SEM $(\boldsymbol{E})$ and SD (G). ML, Molecular layer; PCL, Purkinje cell layer. Scale bars: $\boldsymbol{A}-\boldsymbol{D}, 20 \mu \mathrm{m}$.

Fritschy et al., 2006: Iwakura et al., 2012; Blot and Barbour, 2014). Therefore, impaired PF-interneuron synapse formation in GluD1-KO mice should lead to substantial diminishment of feedforward inhibition to PCs. Conversely, the formation of $\mathrm{PF}-\mathrm{PC}$ synapses that construct the major neural pathway and the maturation process leading to CF mono-innervation are severely disrupted in GluD2-KO mice (Kashiwabuchi et al., 1995; Kurihara et al., 1997; Ichikawa et al., 2002; Miyazaki et al., 2010). Together, GluD1 and GluD2 work in concert to construct the basic synaptic wiring in the cerebellar cortex through distinct neuronal and synaptic expressions and also through their shared synapse-connecting function.

\section{References}

Abe M, Fukaya M, Yagi T, Mishina M, Watanabe M, Sakimura K (2004) NMDA receptor GluRe/NR2 subunits are essential for postsynaptic localization and protein stability of GluR $\zeta 1 / N R 1$ subunit. J Neurosci 24:72927304. CrossRef Medline

Adcock KH, Metzger F, Kapfhammer JP (2004) Purkinje cell dendritic tree development in the absence of excitatory neurotransmission and of brain-derived neurotrophic factor in organotypic slice cultures. Neuroscience 127:137-145. CrossRef Medline

Ady V, Perroy J, Tricoire L, Piochon C, Dadak S, Chen X, Dusart I, Fagni L, Lambolez B, Levenes C (2014) Type 1 metabotropic glutamate receptors (mGlu1) trigger the gating of GluD2 delta glutamate receptors. EMBO Rep 15:103-109. CrossRef Medline

Alvarez-Dolado M, Iglesias T, Rodríguez-Peña A, Bernal J, Muñoz A (1994) Expression of neurotrophins and the trk family of neurotrophin receptors in normal and hypothyroid rat brain. Brain Res Mol Brain Res 27:249257. CrossRef Medline 
Araki K, Meguro H, Kushiya E, Takayama C, Inoue Y, Mishina M (1993) Selective expression of the glutamate receptor channel delta 2 subunit in cerebellar Purkinje cells. Biochem Biophys Res Commun 197:1267-1276. CrossRef Medline

Benisty S, Boissiere F, Faucheux B, Agid Y, Hirsch EC (1998) trkB messenger RNA expression in normal human brain and in the substantia nigra of parkinsonian patients: an in situ hybridization study. Neuroscience 86: 813-826. CrossRef Medline

Blot A, Barbour B (2014) Ultra-rapid axon-axon ephaptic inhibition of cerebellar Purkinje cells by the pinceau. Nat Neurosci 17:289-295. CrossRef Medline

Carlin RK, Grab DJ, Cohen RS, Siekevitz P (1980) Isolation and characterization of postsynaptic densities from various brain regions: enrichment of different types of postsynaptic densities. J Cell Biol 86:831-845. CrossRef Medline

Carter AR, Chen C, Schwartz PM, Segal RA (2002) Brain-derived neurotrophic factor modulates cerebellar plasticity and synaptic ultrastructure. J Neurosci 22:1316-1327. Medline

Cooper GM, Coe BP, Girirajan S, Rosenfeld JA, Vu TH, Baker C, Williams C, Stalker H, Hamid R, Hannig V, Abdel-Hamid H, Bader P, McCracken E, Niyazov D, Leppig K, Thiese H, Hummel M, Alexander N, Gorski J, Kussmann J, et al. (2011) A copy number variation morbidity map of developmental delay. Nat Genet 43:838-846. CrossRef Medline

Edwards AC, Aliev F, Bierut LJ, Bucholz KK, Edenberg H, Hesselbrock V, Kramer J, Kuperman S, Nurnberger JI Jr, Schuckit MA, Porjesz B, Dick DM (2012) Genome-wide association study of comorbid depressive syndrome and alcohol dependence. Psychiatr Genet 22:31-41. CrossRef Medline

Fallin MD, Lasseter VK, Avramopoulos D, Nicodemus KK, Wolyniec PS, McGrath JA, Steel G, Nestadt G, Liang KY, Huganir RL, Valle D, Pulver AE (2005) Bipolar I disorder and schizophrenia: a 440-single-nucleotide polymorphism screen of 64 candidate genes among Ashkenazi Jewish case-parent trios. Am J Hum Genet 77:918-936. CrossRef Medline

Freund TF (2003) Interneuron Diversity series: Rhythm and mood in perisomatic inhibition. Interneuron Diversity series: Rhythm and mood in perisomatic inhibition. Trends Neurosci 26:489-495. CrossRef Medline

Fritschy JM, Panzanelli P, Kralic JE, Vogt KE, Sassoè-Pognetto M (2006) Differential dependence of axo-dendritic and axo-somatic GABAergic synapses on $\mathrm{GABA}_{\mathrm{A}}$ receptors containing the alphal subunit in Purkinje cells. J Neurosci 26:3245-3255. CrossRef Medline

Gao J, Maison SF, Wu X, Hirose K, Jones SM, Bayazitov I, Tian Y, Mittleman G, Matthews DB, Zakharenko SS, Liberman MC, Zuo J (2007) Orphan glutamate receptor deltal subunit required for high-frequency hearing. Mol Cell Biol 27:4500-4512. CrossRef Medline

Gao WQ, Zheng JL, Karihaloo M (1995) Neurotrophin-4/5 (NT-4/5) and brain-derived neurotrophic factor (BDNF) act at later stages of cerebellar granule cell differentiation. J Neurosci 15:2656-2667. Medline

Glessner JT, Wang K, Cai G, Korvatska O, Kim CE, Wood S, Zhang H, Estes A, Brune CW, Bradfield JP, Imielinski M, Frackelton EC, Reichert J, Crawford EL, Munson J, Sleiman PM, Chiavacci R, Annaiah K, Thomas K, Hou C, et al. (2009) Autism genome-wide copy number variation reveals ubiquitin and neuronal genes. Nature 459:569-573. CrossRef Medline

Greenwood TA, Lazzeroni LC, Murray SS, Cadenhead KS, Calkins ME, Dobie DJ, Green MF, Gur RE, Gur RC, Hardiman G, Kelsoe JR, Leonard S, Light GA, Nuechterlein KH, Olincy A, Radant AD, Schork NJ, Seidman LJ, Siever LJ, Silverman JM, et al. (2011) Analysis of 94 candidate genes and 12 endophenotypes for schizophrenia from the Consortium on the Genetics of Schizophrenia. Am J Psychiatry 168:930-946. CrossRef Medline

Griswold AJ, Ma D, Cukier HN, Nations LD, Schmidt MA, Chung RH, Jaworski JM, Salyakina D, Konidari I, Whitehead PL, Wright HH, Abramson RK, Williams SM, Menon R, Martin ER, Haines JL, Gilbert JR, Cuccaro ML, Pericak-Vance MA (2012) Evaluation of copy number variations reveals novel candidate genes in autism spectrum disorderassociated pathways. Hum Mol Genet 21:3513-3523. CrossRef Medline

Guastavino JM, Sotelo C, Damez-Kinselle I (1990) Hot-foot murine mutation: behavioral effects and neuroanatomical alterations. Brain Res 523: 199-210. CrossRef Medline

Guo SZ, Huang K, Shi YY, Tang W, Zhou J, Feng GY, Zhu SM, Liu HJ, Chen Y, Sun XD, He L (2007) A case-control association study between the GRID1 gene and schizophrenia in the Chinese Northern Han population. Shizophr Res 93:385-390. CrossRef
Hills LB, Masri A, Konno K, Kakegawa W, Lam AT, Lim-Melia E, Chandy N, Hill RS, Partlow JN, Al-Saffar M, Nasir R, Stoler JM, Barkovich AJ, Watanabe M, Yuzaki M, Mochida GH (2013) Deletions in GRID2 lead to a recessive syndrome of cerebellar ataxia and tonic upgaze in humans. Neurology 81:1378-1386. CrossRef Medline

Hioki H, Nakamura H, Ma YF, Konno M, Hayakawa T, Nakamura KC, Fujiyama F, Kaneko T (2010) Vesicular glutamate transporter 3 -expressing nonserotonergic projection neurons constitute a subregion in the rat midbrain raphe nuclei. J Comp Neurol 518:668-686. CrossRef Medline

Hirai H, Launey T, Mikawa S, Torashima T, Yanagihara D, Kasaura T, Miyamoto A, Yuzaki M (2003) New role of delta2-glutamate receptors in AMPA receptor trafficking and cerebellar function. Nat Neurosci 6:869876. CrossRef Medline

Hirai H, Miyazaki T, Kakegawa W, Matsuda S, Mishina M, Watanabe M, Yuzaki M (2005) Rescue of abnbormal phenotypes of the $\delta 2$ glutamate receptor-null mice by mutant $\delta 2$ transgenes. EMBO Rep 6:90-95. CrossRef Medline

Ichikawa R, Miyazaki T, Kano M, Hashikawa T, Tatsumi H, Sakimura K, Mishina M, Inoue Y, Watanabe M (2002) Distal extension of climbing fiber territory and multiple innervation caused by aberrant wiring to adjacent spiny branchlets in cerebellar Purkinje cells lacking glutamate receptor delta 2. J Neurosci 22:8487-8503. Medline

Ito-Ishida A, Miura E, Emi K, Matsuda K, Iijima T, Kondo T, Kohda K, Watanabe M, Yuzaki M (2008) Cbln1 regulates rapid formation and maintenance of excitatory synapses in mature cerebellar Purkinje cells in vitro and in vivo. J Neurosci 28:5920-5930. CrossRef Medline

Iwakura A, Uchigashima M, Miyazaki T, Yamasaki M, Watanabe M (2012) Lack of molecular-anatomical evidence for GABAergic influence upon axon initial segment of cerebellar Purkinje cells by the pinceau formation. J Neurosci 32:9438-9448. CrossRef Medline

Kakegawa W, Kohda K, Yuzaki M (2007a) The delta2 "ionotropic” glutamate receptor functions as a non-ionotropic receptor to control cerebellar synaptic plasticity. J Physiol 584:89-96. CrossRef Medline

Kakegawa W, Miyazaki T, Hirai H, Motohashi J, Mishina M, Watanabe M, Yuzaki M (2007b) $\mathrm{Ca}^{2+}$ permeability of the channel pore is not essential for the $\delta 2$ glutamate receptor to regulate synaptic plasticity and motor coordination. J Physiol 579:729-735. CrossRef Medline

Kakegawa W, Miyoshi Y, Hamase K, Matsuda S, Matsuda K, Kohda K, Emi K, Motohashi J, Konno R, Zaitsu K, Yuzaki M (2011) D-serine regulates cerebellar LTD and motor coordination through the $\delta 2$ glutamate receptor. Nat Neurosci 14:603-611. CrossRef Medline

Kashiwabuchi N, Ikeda K, Araki K, Hirano T, Shibuki K, Takayama C, Inoue Y, Kutsuwada T, Yagi T, Kang Y, Aizawa S, Mishina M (1995) Impairment of motor coordination Purkinje cell synapse formation and cerebellar long-term depression in GluR $\delta 2$ mutant mice. Cell 81:245-252. CrossRef Medline

Klein R, Martin-Zanca D, Barbacid M, Parada LF (1990) Expression of the tyrosine kinase receptor gene trkB is confined to the murine embryonic and adult nervous system. Development 109:845-850. Medline

Kohda K, Kakegawa W, Matsuda S, Yamamoto T, Hirano H, Yuzaki M (2013) The $\delta 2$ glutamate receptor gates long-term depression by coordinating interactions between two AMPA receptor phosphorylation sites. Proc Natl Acad Sci U S A 110:E948-957. CrossRef Medline

Korn H, Axelrad H (1980) Electrical inhibition of Purkinje cells in the cerebellum of the rat. Proc Natl Acad Sci U S A 77:6244-6247. CrossRef Medline

Kurihara H, Hashimoto K, Kano M, Takayama C, Sakimura K, Mishina M, Inoue Y, Watanabe M (1997) Impaired parallel fiber->Purkinje cell synapse stabilization during cerebellar development of mutant mice lacking the glutamate receptor delta2 subunit. J Neurosci 17:9613-9623. Medline

Lalouette A, Lohof A, Sotelo C, Guénet J, Mariani J (2001) Neurobiological effects of a null mutation depend on genetic context: comparison between two hotfoot alleles of the delta-2 ionotropic glutamate receptor. Neuroscience 105:443-455. CrossRef Medline

Landsend AS, Amiry-Moghaddam M, Matsubara A, Bergersen L, Usami S, Wenthold RJ, Ottersen OP (1997) Differential localization of delta glutamate receptors in the rat cerebellum: coexpression with AMPA receptors in parallel fiber-spine synapses and absence from climbing fiber-spine synapses. J Neurosci 17:834-842. Medline 
Lindholm D, Hamnér S, Zirrgiebel U (1997) Neurotrophins and cerebellar development. Perspect Dev Neurobiol 5:83-94. Medline

Lomeli H, Sprengel R, Laurie DJ, Köhr G, Herb A, Seeburg PH, Wisden W (1993) The rat delta-l and delta-2 subunits extend the excitatory amino acid receptor family. FEBS Lett 315:318-322. CrossRef Medline

Matsuda K, Miura E, Miyazaki T, Kakegawa W, Emi K, Narumi S, Fukazawa Y, Ito-Ishida A, Kondo T, Shigemoto R, Watanabe M, Yuzaki M (2010) Cbln1 is a ligand for an orphan glutamate receptor delta2, a bidirectional synapse organizer. Science 328:363-368. CrossRef Medline

Mertz K, Koscheck T, Schilling K (2000) Brain-derived neurotrophic factor modulates dendritic morphology of cerebellar basket and stellate cells: an in vitro study. Neuroscience 97:303-310. CrossRef Medline

Miura E, Fukaya M, Sato T, Sugihara K, Asano M, Yoshioka K, Watanabe M (2006) Expression and distribution of JNK/SAPK-associated scaffold protein JSAP1 in developing and adult mouse brain. J Neurochem 97: 1431-1446. CrossRef Medline

Miura E, Matsuda K, Morgan JI, Yuzaki M, Watanabe M (2009) Cbln1 accumulates and colocalizes with Cbln 3 and GluRdelta2 at parallel fiber-Purkinje cell synapses in the mouse cerebellum. Eur J Neurosci 29:693-706. CrossRef Medline

Miyazaki T, Fukaya M, Shimizu H, Watanabe M (2003) Subtype switching of vesicular glutamate transporters at parallel fibre-Purkinje cell synapses in developing mouse cerebellum. Eur J Neurosci 17:2563-2572. CrossRef Medline

Miyazaki T, Yamasaki M, Takeuchi T, Sakimura K, Mishina M, Watanabe M (2010) Ablation of glutamate receptor GluR $\delta 2$ in adult Purkinje cells causes multiple innervation of climbing fibers by inducing aberrant invasion to parallel fiber innervation territory. J Neurosci 30:15196-25209. CrossRef Medline

Nakamura M, Sato K, Fukaya M, Araishi K, Aiba A, Kano M, Watanabe M (2004) Signaling complex formation of phospholipase C $\beta 4$ with mGluR $1 \alpha$ and IP3R 1 at the perisynapse and endoplasmic reticulum in the mouse brain. Eur J Neurosci 20:2929-2944. CrossRef Medline

Palay S, Chan-Palay V (1974) Cerebellar cortex: cytology and organization. New York: Springer.

Rico B, Xu B, Reichardt LF (2002) TrkB receptor signaling is required for establishment of GABAergic synapses in the cerebellum. Nat Neurosci 5:225-233. CrossRef Medline

Ryu K, Yokoyama M, Yamashita M, Hirano T (2012) Induction of excitatory and inhibitory presynaptic differentiation by GluD1. Biochem Biophys Res Commun 417:157-161. CrossRef Medline

Schwartz PM, Borghesani PR, Levy RL, Pomeroy SL, Segal RA (1997) Abnormal cerebellar development and foliation in $\mathrm{BDNF}^{-/-}$mice reveals a role for neurotrophins in CNS patterning. Neuron 19:269-281. CrossRef Medline

Segal RA, Pomeroy SL, Stiles CD (1995) Axonal growth and fasciculation linked to differential expression of BDNF and NT3 receptors in developing cerebellar granule cells. J Neurosci 15:4970-4981. Medline

Seil FJ (2003) TrkB receptor signaling and activity-dependent inhibitory synaptogenesis. Histol Histopathol 18:635-646. Medline

Smith M, Spence MA, Flodman P (2009) Nuclear and mitochondrial genome defects in autisms. Ann N Y Acad Sci 1151:102-132. CrossRef Medline

Spatkowski G, Schilling K (2003) Postnatal dendritic morphogenesis of cerebellar basket and stellate cells in vitro. J Neurosci Res 72:317-326. CrossRef Medline

Takayama C, Nakagawa S, Watanabe M, Mishina M, Inoue Y (1996) Developmental changes in expression and distribution of the glutamate recep- tor channel delta 2 subunit according to the Purkinje cell maturation. Brain Res Dev Brain Res 92:147-155. CrossRef Medline

Takeuchi T, Miyazaki T, Watanabe M, Mori H, Sakimura K, Mishina M (2005) Control of synaptic connection by glutamate receptor $\delta 2$ in the mature cerebellum. J Neurosci 25:2146-2156. CrossRef Medline

Treutlein J, Mühleisen TW, Frank J, Mattheisen M, Herms S, Ludwig KU, Treutlein T, Schmael C, Strohmaier J, Bösshenz KV, Breuer R, Paul T, Witt SH, Schulze TG, Schlösser RG, Nenadic I, Sauer H, Becker T, Maier W, Cichon S, et al. (2009) Dissection of phenotype reveals possible association between schizophrenia and Glutamate Receptor Delta 1 (GRID1) gene promoter. Shizophr Res 111:123-130. CrossRef Medline

Uemura T, Lee SJ, Yasumura M, Takeuchi T, Yoshida T, Ra M, Taguchi R, Sakimura K, Mishina M (2010) Trans-synaptic interaction of GluRdelta2 and Neurexin through Cbln1 mediates synapse formation in the cerebellum. Cell 141:1068-1079. CrossRef Medline

Utine GE, Haliloğlu G, Salanci B, Çetinkaya A, Kiper PÖ, Alanay Y, Aktas D, Boduroğlu K, Alikaşifoğlu M (2013) A homozygous deletion in GRID2 causes a human phenotype with cerebellar ataxia and atrophy. J Child Neurol 228:926-932. CrossRef Medline

Watanabe M, Kano M (2011) Climbing fiber synapse elimination in cerebellar Purkinje cells. Eur J Neurosci 34:1697-1710. CrossRef Medline

Watanabe M, Fukaya M, Sakimura K, Manabe T, Mishina M, Inoue Y (1998) Selective scarcity of NMDA receptor channel subunits in the stratum lucidum (mossy fibre-recipient layer) of the mouse hippocampal CA3 subfield. Eur J Neurosci 10:478-487. CrossRef Medline

Yadav R, Gupta SC, Hillman BG, Bhatt JM, Stairs DJ, Dravid SM (2012) Deletion of glutamate delta-1 receptor in mouse leads to aberrant emotional and social behaviors. PLoS One 7:e32969. CrossRef Medline

Yadav R, Hillman BG, Gupta SC, Suryavanshi P, Bhatt JM, Pavuluri R, Stairs DJ, Dravid SM (2013) Deletion of glutamate delta-1 receptor in mouse leads to enhanced working memory and deficit in fear conditioning. PLoS One 8:e60785. CrossRef Medline

Yamasaki M, Matsui M, Watanabe M (2010) Preferential localization of muscarinic M1 receptor on dendritic shaft and spine of cortical pyramidal cells and its anatomical evidence for volume transmission. J Neurosci 30:4408-4418. CrossRef Medline

Yamasaki M, Miyazaki T, Azechi H, Abe M, Natsume R, Hagiwara T, Aiba A, Mishina M, Sakimura K, Watanabe M (2011) Glutamate receptor $\delta 2$ is essential for input pathway-dependent regulation of synaptic AMPAR contents in cerebellar Purkinje cells. J Neurosci 31:3362-3374. CrossRef Medline

Yamazaki M, Araki K, Shibata A, Mishina M (1992) Molecular cloning of a cDNA encoding a novel member of the mouse glutamate receptor channel family. Biochem Biophys Res Commun 183:886-892. CrossRef Medline

Yasumura M, Yoshida T, Lee SJ, Uemura T, Joo JY, Mishina M (2012) Glutamate receptor $\delta 1$ induces preferentially inhibitory presynaptic differentiation of cortical neurons by interacting with neurexins through cerebellin precursor protein subtypes. J Neurochem 121:705-716. CrossRef Medline

Yuzaki M (2009) New (but old) molecules regulating synapse integrity and plasticity: Cbln1 and the delta2 glutamate receptor. Neuroscience 162 : 633-643. CrossRef Medline

Zanjani SH, Selimi F, Vogel MW, Haeberlé AM, Boeuf J, Mariani J, Bailly YJ (2006) Survival of interneurons and parallel fiber synapses in a cerebellar cortex deprived of Purkinje cells: studies in the double mutant mouse Grid2Lc/+;Bax(-/-). J Comp Neurol 497:622-635. CrossRef Medline 